\title{
A critical evaluation of proxy methods used to estimate the acidity of atmospheric particles
}

\author{
C. J. Hennigan ${ }^{1}$, J. Izumi ${ }^{1}$, A. P. Sullivan ${ }^{2}$, R. J. Weber ${ }^{3}$, and A. Nenes ${ }^{3,4,5}$ \\ ${ }^{1}$ Department of Chemical, Biochemical and Environmental Engineering, University of Maryland, \\ Baltimore County, Baltimore, MD, USA \\ ${ }^{2}$ Department of Atmospheric Science, Colorado State University, Fort Collins, CO, USA \\ ${ }^{3}$ School of Earth and Atmospheric Sciences, Georgia Institute of Technology, Atlanta, GA, USA \\ ${ }^{4}$ School of Chemical and Biomolecular Engineering, Georgia Institute of Technology, Atlanta, GA, USA \\ ${ }^{5}$ Foundation for Research and Technology - Hellas, Patras, Greece \\ Correspondence to: C. J. Hennigan (hennigan@umbc.edu)
}

Received: 9 October 2014 - Published in Atmos. Chem. Phys. Discuss.: 5 November 2014

Revised: 14 January 2015 - Accepted: 12 February 2015 - Published: 10 March 2015

\begin{abstract}
Given significant challenges with available measurements of aerosol acidity, proxy methods are frequently used to estimate the acidity of atmospheric particles. In this study, four of the most common aerosol acidity proxies are evaluated and compared: (1) the ion balance method, (2) the molar ratio method, (3) thermodynamic equilibrium models, and (4) the phase partitioning of ammonia. All methods are evaluated against predictions of thermodynamic models and against direct observations of aerosol-gas equilibrium partitioning acquired in Mexico City during the Megacity Initiative: Local and Global Research Objectives (MILAGRO) study. The ion balance and molar ratio methods assume that any deficit in inorganic cations relative to anions is due to the presence of $\mathrm{H}^{+}$and that a higher $\mathrm{H}^{+}$loading and lower cation/anion ratio both correspond to increasingly acidic particles (i.e., lower $\mathrm{pH}$ ). Based on the MILAGRO measurements, no correlation is observed between $\mathrm{H}^{+}$levels inferred with the ion balance and aerosol $\mathrm{pH}$ predicted by the thermodynamic models and $\mathrm{NH}_{3}-\mathrm{NH}_{4}^{+}$partitioning. Similarly, no relationship is observed between the cation / anion molar ratio and predicted aerosol $\mathrm{pH}$. Using only measured aerosol chemical composition as inputs without any constraint for the gas phase, the E-AIM (Extended Aerosol Inorganics Model) and ISORROPIA-II thermodynamic equilibrium models tend to predict aerosol $\mathrm{pH}$ levels that are inconsistent with the observed $\mathrm{NH}_{3}-\mathrm{NH}_{4}^{+}$partitioning. The modeled $\mathrm{pH}$ values from both E-AIM and ISORROPIA-II run with gas + aerosol inputs agreed well with the aerosol $\mathrm{pH}$
\end{abstract}

predicted by the phase partitioning of ammonia. It appears that (1) thermodynamic models constrained by gas + aerosol measurements and (2) the phase partitioning of ammonia provide the best available predictions of aerosol $\mathrm{pH}$. Furthermore, neither the ion balance nor the molar ratio can be used as surrogates for aerosol $\mathrm{pH}$, and previously published studies with conclusions based on such acidity proxies may need to be reevaluated. Given the significance of acidity for chemical processes in the atmosphere, the implications of this study are important and far reaching.

\section{Introduction}

The acidity of atmospheric particles is a critical parameter that affects air quality and the health of aquatic and terrestrial ecosystems. Acute and chronic exposures to acidic particles have been linked to deleterious effects in people, although the underlying physiological mechanisms are unclear (Gwynn et al., 2000; Dockery et al., 1996). The deposition of acidic gases and particles has been known for decades to damage freshwater and terrestrial ecosystems (Schindler, 1988; Johnson et al., 2008). While the trends in emissions are promising in the US and western Europe, ecosystem recovery from the effects of acid deposition is a slow process that can take decades (Likens et al., 1996; Stoddard et al., 1999). This may be a source of emerging environmental crisis in places such as China, where acid deposition is increas- 
ing due to rapid industrialization (Pan et al., 2013; Cao et al., 2013). Particle acidity also affects global biogeochemical cycles by controlling the solubility - and thus bioavailability of limiting nutrients that are delivered through atmospheric deposition in many marine environments (Meskhidze et al., 2003, 2005; Nenes et al., 2011). This has important implications for marine primary productivity, the carbon cycle, and even climate (Mahowald, 2011).

Particle acidity is also a critical factor that influences many chemical processes in the atmosphere. The oxidation of S(IV) to S(VI) in liquid water, the primary pathway of sulfate formation, is highly sensitive to $\mathrm{pH}$ (Chameides, 1984). Halogen chemistry is strongly influenced by particle acidity, which has direct implications for the oxidation of volatile organic compounds (VOCs) and ozone formation in marine and coastal regions (e.g., Keene et al., 1998; Sander and Crutzen, 1996; Pszenny et al., 2004). Recent evidence has demonstrated that aerosol $\mathrm{pH}$ is also a critical parameter influencing halogen chemistry in continental locations (Brown et al., 2013; Thornton et al., 2010; Young et al., 2013). Further, aerosol acidity directly affects the deposition and lifetime of many compounds in the atmosphere through its influence on the gas-particle partitioning of semi-volatile species, including ammonia $\left(\mathrm{NH}_{3}\right)$, nitric acid $\left(\mathrm{HNO}_{3}\right)$, and organic acids (Ahrens et al., 2012; Keene et al., 2004). Aerosol acidity may affect secondary organic aerosol (SOA) formation, as well (e.g., Gaston et al., 2014; Surratt et al., 2007), although the atmospheric importance of this phenomenon remains highly uncertain (Peltier et al., 2007; Takahama et al., 2006; Tanner et al., 2009; Zhang et al., 2007; Xu et al., 2015).

Despite its significance, aerosol acidity remains very poorly constrained in the atmosphere (Keene et al., 1998). All direct measurements employ filter sampling (e.g., Jang et al., 2008; Keene et al., 2002; Koutrakis et al., 1988), which is both labor intensive and limited by poor time resolution. Measurements are also challenged by the non-conservative nature of $\mathrm{H}^{+}$: due to buffering effects and the partial dissociation of weak acids, $\mathrm{H}^{+}$concentrations do not scale in proportion to the level of dilution (e.g., in aqueous filter extracts). Certain methods are also susceptible to sampling artifacts, which can greatly increase the uncertainty of an inherently challenging measurement (Pathak et al., 2004). Due to these limitations, indirect methods are frequently employed to estimate the acidity of atmospheric particles. These methods include (1) the ion balance method, (2) the molar ratio, (3) thermodynamic equilibrium models, and (4) the phase partitioning of semi-volatile species $\left(\mathrm{HCl}, \mathrm{NH}_{3}, \mathrm{HNO}_{3}\right)$. The purpose of this study is to evaluate and compare the proxy methods most commonly used to estimate aerosol acidity.

\section{Methods to infer $\mathrm{pH}$}

Before proceeding with this analysis, it is necessary to define the different physical quantities commonly described by the term "aerosol acidity". First, it is used to represent the
$\mathrm{pH}$ of an aerosol particle or distribution. The $\mathrm{pH}$ represents the hydrogen ion activity in an aqueous solution (Stumm and Morgan, 1996):

$\mathrm{pH}=-\log \left(\gamma \cdot x_{\mathrm{H}^{+}}\right)$,

where $\gamma$ is the hydrogen ion activity coefficient and $x_{\mathrm{H}^{+}}$is the aqueous mole fraction of dissociated $\mathrm{H}^{+}$. The presence of aerosol water is implicit in this definition since free $\mathrm{H}^{+}$ cannot exist in solid particles. Second, "aerosol acidity" is commonly used to describe the loading of protons in atmospheric particles, in units of $\mathrm{nmol} \mathrm{m}^{-3}$ or neq $\mathrm{m}^{-3}$. This definition can take several forms, including aerosol strong acidity $\left(\mathrm{H}^{+}\right.$contributed by strong acids that dissociate completely at most $\mathrm{pH}$ levels), free acidity (dissociated $\mathrm{H}^{+}$), or total acidity (includes free $\mathrm{H}^{+}$and the undissociated $\mathrm{H}^{+}$bound to weak acids), typically defined by the measurement approach (Keene et al., 2004; Lawrence and Koutrakis, 1996). The major difference between aerosol $\mathrm{pH}$ and the proton loading is that $\mathrm{pH}$ is the $\mathrm{H}^{+}$concentration per liquid water volume (i.e., aerosol water) while the aerosol proton loading is the $\mathrm{H}^{+}$ concentration per unit volume of air. Aerosol $\mathrm{pH}$ is the parameter of interest for the atmospheric phenomena described above, but the proton loading is often treated as a surrogate for $\mathrm{pH}$. This is a critical distinction that will be discussed in detail below, especially in relation to the appropriate use of each parameter for the analysis of chemical processes in the atmosphere.

\subsection{Ion balance method}

The ion balance method is commonly employed to estimate the proton loading in atmospheric particles. This method is based upon the principle of electroneutrality and assumes that any deficit in measured cationic charge compared to measured anionic charge is due to the presence of protons, according to

$\left[\mathrm{H}^{+}\right]=\sum n_{i}\left[\operatorname{anion}_{i}\right]-\sum n_{i}\left[\right.$ cation $\left._{i}\right]$,

where $n_{i}$ is the charge of species, $i$, and $\left[\operatorname{anion}_{i}\right]$ and [cation $\left.{ }_{i}\right]$ are the molar concentrations of anion and cation species, respectively. If the sum of measured cations exceeds that of the measured anions, then the difference is attributed to $\mathrm{OH}^{-}$. $\mathrm{H}^{+}$levels under an anion deficit are then calculated from the inferred $\left[\mathrm{OH}^{-}\right]$using the water dissociation constant, $K_{\mathrm{W}}$. Most applications of the ion balance use inorganic ions only, even though organic acids can be important to the interpretation of aerosol acidity in diverse locations (Lawrence and Koutrakis, 1996; Metzger et al., 2006; Trebs et al., 2005), especially at relatively low acidities where organic acids dissociate and contribute to the ion balance. Neglecting this effect will lead to biases in the inferred $\mathrm{H}^{+}$. Organic compounds can also form salt complexes with inorganic species (e.g., ammonium oxalate) (Reid et al., 1998; Paciga et al., 2014), further indicating the importance of organic acids in the ion balance. 


\subsection{Molar ratio}

While the ion balance method is used to estimate the absolute proton loading in atmospheric particles, the molar ratio is independent of absolute concentrations. The molar ratio is a ratio of the total molar concentration of measured inorganic cations to the measured inorganic anions:

molar ratio $=\sum$ (cations) $/ \sum$ (anions).

It is also frequently employed as an equivalence (charge) ratio. The concept was first introduced in thermodynamic models to define major ions and composition domains (e.g., Pilinis and Seinfeld, 1987; Nenes et al., 1998; Kim et al., 1993; Fountoukis and Nenes, 2007), but never to infer the levels of acidity and $\mathrm{pH}$. Thermodynamic models using the major species/composition domain approach (e.g., Fountoukis and Nenes, 2007) consider the possibility that aerosol species may volatilize enough to affect the ratio at equilibrium. Furthermore, the degree of dissociation of species such as $\mathrm{H}_{2} \mathrm{SO}_{4} / \mathrm{HSO}_{4}^{-} / \mathrm{SO}_{4}^{2-}, \mathrm{HNO}_{3} / \mathrm{NO}_{3}^{-}, \mathrm{HCl} / \mathrm{Cl}^{-}$, and $\mathrm{NH}_{3} / \mathrm{NH}_{4}^{+}$can affect the value of the ratio. In subsequent studies, however, the molar ratio has been treated as a proxy for acidity, with lower ratios corresponding to particles with the highest levels of acidity (lowest pH) (e.g., Kerminen et al., 2001). Molar ratios that yield a charge balance (i.e., equivalence ratios of unity or greater) are assumed for fully neutralized aerosol. Two common simplifications of the molar ratio approach are often applied when the concentrations of crustal elements are relatively low (e.g., Zhang et al., 2007):

molar ratio $=\mathrm{NH}_{4}^{+} /\left(\mathrm{Cl}^{-}+\mathrm{NO}_{3}^{-}+2^{*} \mathrm{SO}_{4}^{2-}\right)$

and (e.g., Peltier et al., 2007; Tanner et al., 2009; Froyd et al., 2010):

molar ratio $=\mathrm{NH}_{4}^{+} /\left(2 * \mathrm{SO}_{4}^{2-}\right)$.

\subsection{Thermodynamic equilibrium models}

Multiple thermodynamic equilibrium models have been developed to predict the behavior - most commonly the phase partitioning, liquid water content, and chemical speciation of inorganic aerosol precursors. Previous studies have performed detailed comparisons and have explored the causes of disagreement among different thermodynamic equilibrium models (Ansari and Pandis, 1999; Zhang et al., 2000). We do not attempt to repeat this exercise. Instead, thermodynamic models are considered as one method to estimate the acidity of atmospheric particles. Two models are used in the present analysis: ISORROPIA-II (Fountoukis and Nenes, 2007; Nenes et al., 1999) and the Extended Aerosol Inorganics Model (E-AIM) (Clegg et al., 1998, 2003; Wexler and Clegg, 2002). ISORROPIA-II was designed with high computational efficiency to facilitate its incorporation in largescale models and has seen wide usage. E-AIM is computationally expensive but is considered the benchmark since it employs few assumptions in its calculation of aerosol inorganic behavior (Zaveri et al., 2008).

Two applications of each model are considered (Fountoukis et al., 2009): (a) "forward" (or "closed") mode calculations, in which inputs to the model include $T$, relative humidity (RH), and the total (gas + aerosol) concentrations of aerosol precursors in the air parcel, and, (b) "reverse" (or "open") calculations, in which inputs to the model include $T, \mathrm{RH}$, and the concentration of aerosol species. The output of both calculations is the concentration of species in the gas and aerosol (solid/liquid) phases, $\mathrm{pH}$, and aerosol water. Highly time-resolved measurements of aerosol composition (e.g., via PILS-IC or AMS) are frequently conducted without the corresponding gas-phase aerosol precursor measurements $\left(\mathrm{HCl}, \mathrm{HNO}_{3}, \mathrm{NH}_{3}\right)$. Under this condition, it is conceptually straightforward to run the thermodynamic models in reverse mode, and this approach is frequently applied to analyze ambient and experimental data. In this analysis, we consider aerosol acidity predictions using both methods.

\subsection{Phase partitioning}

Aerosol $\mathrm{pH}$ can also be estimated from the phase partitioning of certain semi-volatile compounds, such as $\mathrm{HNO}_{3} / \mathrm{NO}_{3}^{-}$, $\mathrm{NH}_{3} / \mathrm{NH}_{4}^{+}$, and $\mathrm{HCl} / \mathrm{Cl}^{-}$(e.g., Keene et al., 2004; Meskhidze et al., 2003). The $\mathrm{H}^{+}$concentration in aqueous particles can be calculated assuming that the system is in equilibrium (using $\mathrm{NH}_{3} / \mathrm{NH}_{4}^{+}$as an example):

$\mathrm{NH}_{3}(\mathrm{~g}) \leftrightarrow \mathrm{NH}_{3}(\mathrm{aq}) \quad K_{\mathrm{H}}$,

$$
\mathrm{NH}_{3}(\mathrm{aq})+\mathrm{H}_{2} \mathrm{O} \leftrightarrow \mathrm{NH}_{4}^{+}+\mathrm{OH}^{-} \quad K_{\mathrm{b}} .
$$

Under this approach, both the gas-phase and aerosol ionic components are measured, and the liquid $\mathrm{H}^{+}$concentration can be calculated after combining the equilibrium expressions from Reactions (R1) and (R2):

$$
\left\{\mathrm{H}^{+}\right\}=\frac{K_{\mathrm{w}}\left\{\mathrm{NH}_{4}^{+}\right\}}{K_{\mathrm{H}} K_{\mathrm{b}} p_{\mathrm{NH}_{3}}},
$$

where $\left\{\mathrm{H}^{+}\right\}$is the activity of $\mathrm{H}^{+}$in atmospheric particles, $K_{\mathrm{H}}$ is the temperature-dependent Henry's law constant, $K_{\mathrm{b}}$ is the temperature-dependent base dissociation constant, $K_{\mathrm{w}}$ is the temperature-dependent water dissociation constant, $p_{\mathrm{NH}_{3}}$ is the gas-phase partial pressure of ammonia, and $\left\{\mathrm{NH}_{4}^{+}\right\}$is the activity of aqueous aerosol ammonium. The aerosol liquid water content is required to derive $\left\{\mathrm{NH}_{4}^{+}\right\}$(e.g., to convert from $\mu \mathrm{g} \mathrm{m}^{-3}$ to $\mathrm{mol} \mathrm{L}^{-1}$ ). The $\mathrm{H}^{+}$and $\mathrm{NH}_{4}^{+}$activity coefficients can also be calculated from thermodynamic equilibrium models in order to convert concentrations to activities, although the simplifying assumption of $\gamma=1$ is sometimes employed, with satisfactory results (Fountoukis and Nenes, 2007). 
Table 1. Overview of MILAGRO measurements used as modeling inputs.

\begin{tabular}{|c|c|c|c|c|c|}
\hline \multicolumn{6}{|c|}{ Measurement overview } \\
\hline Species & $\begin{array}{l}\text { Measurement } \\
\text { dates (2006) }\end{array}$ & $\begin{array}{c}\text { Study } \\
n\end{array}$ & $\begin{array}{c}\text { Mean } \\
\text { concentration } \pm \\
1 \sigma\left(\mu \mathrm{g} \mathrm{m}^{-3}\right)\end{array}$ & $\begin{array}{l}\text { 5th percentile } \\
\qquad\left(\mu \mathrm{g} \mathrm{m}^{-3}\right)\end{array}$ & $\begin{array}{l}\text { 95th percentile } \\
\qquad\left(\mu \mathrm{g} \mathrm{m}^{-3}\right)\end{array}$ \\
\hline $\mathrm{Na}^{+}$ & 10 Mar-1 Apr & 998 & $0.31 \pm 0.14$ & 0.18 & 0.45 \\
\hline $\mathrm{NH}_{4}^{+}$ & $10 \mathrm{Mar}-1 \mathrm{Apr}$ & 1159 & $1.69 \pm 1.36$ & 0.25 & 4.43 \\
\hline $\mathrm{Ca}^{2+}$ & $10 \mathrm{Mar}-1 \mathrm{Apr}$ & 1654 & $0.53 \pm 0.57$ & $0.02^{\mathrm{b}}$ & 1.64 \\
\hline $\mathrm{Mg}^{2+}$ & $10 \mathrm{Mar}-1 \mathrm{Apr}$ & 1051 & $0.15 \pm 0.07$ & 0.08 & 0.28 \\
\hline $\mathrm{Cl}^{-}$ & $10 \mathrm{Mar}-1 \mathrm{Apr}$ & 1603 & $0.27 \pm 0.69$ & $0.02^{\mathrm{b}}$ & 1.23 \\
\hline $\mathrm{NO}_{3}^{-}$ & 10 Mar-1 Apr & 1634 & $2.93 \pm 2.66$ & 0.37 & 8.20 \\
\hline $\mathrm{SO}_{4}^{2-}$ & $10 \mathrm{Mar}-1 \mathrm{Apr}$ & 1652 & $3.74 \pm 2.30$ & 1.63 & 8.05 \\
\hline $\mathrm{NH}_{3}{ }^{\mathrm{a}}$ & $21 \mathrm{Mar}-31 \mathrm{Mar}$ & 9594 & $25.2 \pm 15.3$ & 7.9 & 56.1 \\
\hline $\mathrm{HNO}_{3}{ }^{\mathrm{a}}$ & 17 Mar-30 Mar & 430 & $2.43 \pm 1.48$ & 0.71 & 5.11 \\
\hline
\end{tabular}

Table 2. Overview of modeling outputs and criteria.

\begin{tabular}{|c|c|c|c|c|c|}
\hline \multicolumn{6}{|l|}{ Modeling overview } \\
\hline Model & $n$ & $\begin{array}{l}\text { Average }\left[\mathrm{H}^{+}\right] \\
\left(\mathrm{nmol} \mathrm{m}^{-3}\right)\end{array}$ & $\begin{array}{l}\text { Median }\left[\mathrm{H}^{+}\right] \\
\left(\mathrm{nmol} \mathrm{m}^{-3}\right)\end{array}$ & $\begin{array}{l}\text { Average } \\
\mathrm{pH}\end{array}$ & $\begin{array}{r}\text { Median } \\
\mathrm{pH}\end{array}$ \\
\hline ISORROPIA-II, reverse ${ }^{1}$ & 438 & 19.39 & 10.34 & 1.98 & -0.02 \\
\hline E-AIM, reverse ${ }^{1}$ & 460 & 15.77 & 6.56 & 2.36 & 0.14 \\
\hline ISORROPIA-II, forward ${ }^{2}$ & 89 & 0.008 & 0.005 & 3.31 & 3.38 \\
\hline E-AIM, forward ${ }^{2}$ & 39 & 0.015 & 0.012 & 3.24 & 3.32 \\
\hline
\end{tabular}

\subsection{Evaluation data set}

We evaluate the above methods using ground-based data collected during the Megacity Initiative: Local and Global Research Objectives (MILAGRO) campaign at the T1 site in Mexico City (Molina et al., 2010). The measurements spanned 10 March-1 April 2006 (Table 1). Inorganic $\mathrm{PM}_{2.5}$ composition $\left(\mathrm{Na}^{+}, \mathrm{NH}_{4}^{+}, \mathrm{K}^{+}, \mathrm{Mg}^{2+}, \mathrm{Ca}^{2+}, \mathrm{Cl}^{-}, \mathrm{NO}_{3}^{-}\right.$, and $\mathrm{SO}_{4}^{2-}$ ) was measured with a Particle-into-Liquid Sampler coupled to a dual ion chromatograph (Hennigan et al., 2008). Six-minute integrated measurements were conducted every 15 min. Given that $\mathrm{PM}_{2.5}$ composition only was measured, no size-acidity dependence could be elucidated (Keene et al., 2002). Ammonia was measured with a quantum cascade laser spectrometer with $1 \mathrm{~min}$ sample time resolution (Aerodyne Research, Inc.). Nitric acid was measured with 5 min time resolution via thermal-dissociation laser-induced fluorescence of nitrogen oxides (Day et al., 2002; Farmer et al., 2011). All chloride was assumed to reside in the particle phase (i.e., gas-phase $\mathrm{HCl}$ was effectively 0 ), which was de- termined to be a valid assumption given the high concentrations of gas-phase $\mathrm{NH}_{3}$ (Fountoukis et al., 2009).

The chemical measurements, along with ambient temperature and RH, were used as inputs into ISORROPIA-II and E-AIM. Fountoukis et al. (2009) evaluated the equilibrium partitioning of semi-volatile compounds at $\mathrm{T} 1 \mathrm{using}$ ISORROPIA-II. We do not duplicate that effort here: instead, we focus solely on particle acidity and the comparison across the different proxy methods described above. For the reverse model runs, the 1 min met data were averaged to the aerosol sampling times and were used in conjunction with the aerosol concentrations as model inputs. Given the differences in sample timing, the forward model runs used as inputs the total gas + aerosol concentrations and met data averaged to common 10 min sample times. Output from the reverse model runs was used for the present analysis only if the following criteria were met for a given sample: (1) $\mathrm{NH}_{4}^{+}, \mathrm{NO}_{3}^{-}$, and $\mathrm{SO}_{4}^{2-}$ aerosol measurements were operational; (2) $\mathrm{RH}>40 \%$; and (3) modeled aerosol liquid water $>0$. Output from the forward model runs was used 


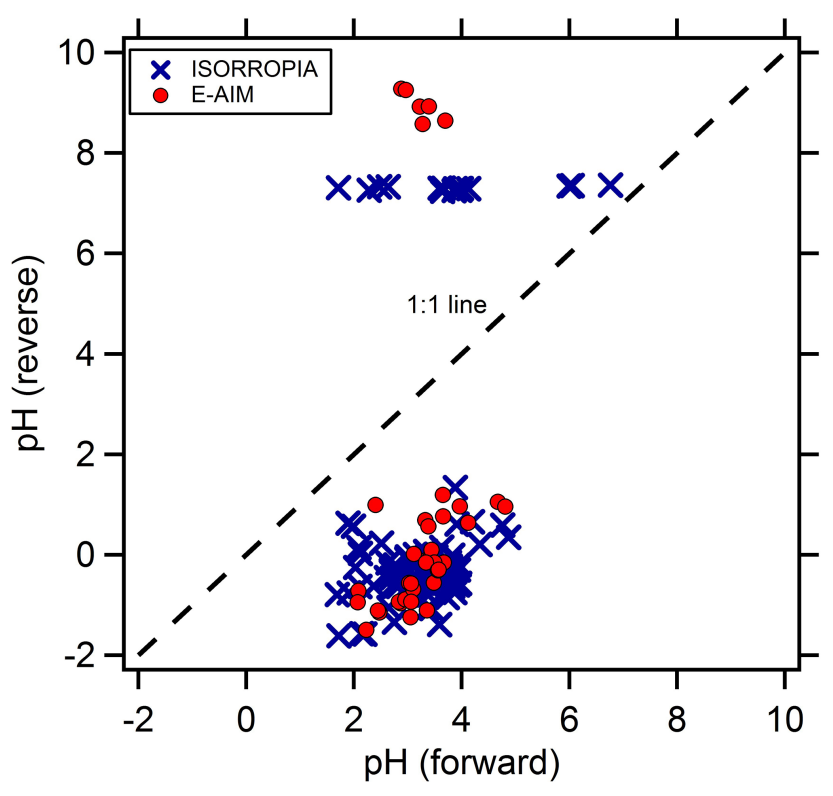

Figure 1. Comparison of $\mathrm{pH}$ predicted using the reverse and forward modes of ISORROPIA and E-AIM.

for the present analysis only if the above criteria were met, and both the $\mathrm{NH}_{3}$ and $\mathrm{HNO}_{3}$ measurements were operational for a given sampling interval. These constraints explain the differences in sample numbers between the forward and reverse simulations and between E-AIM and ISORROPIA (Table 2). ISORROPIA-II model runs were performed in "metastable" mode where the aerosol is only in the aqueous phase and can be supersaturated (http://isorropia.eas.gatech. edu/). ISORROPIA treats the $\mathrm{Na}^{+}-\mathrm{NH}_{4}^{+}-\mathrm{K}^{+}-\mathrm{Ca}^{2+}-\mathrm{Mg}^{2+}{ }_{-}$ $\mathrm{Cl}^{-}-\mathrm{NO}_{3}^{-}-\mathrm{SO}_{4}^{2-}$ system. For conditions of excess cations, ISORROPIA-II assumes that bicarbonate $\left(\mathrm{HCO}_{3}^{-}\right)$and carbonate $\left(\mathrm{CO}_{3}^{2-}\right)$ account for the deficit, and a $\mathrm{pH}$ limit of 7 is imposed. Model version AIM-IV was used for RH conditions greater than $60 \%(n=348$, Table 2$)$, and model version AIM-II was used for RH conditions between 40 and $60 \%$ ( $n=112$, Table 2) (http://www.aim.env.uea.ac.uk/aim/aim. php). AIM-IV treats the $\mathrm{Na}^{+}-\mathrm{NH}_{4}^{+}-\mathrm{Cl}^{-}-\mathrm{NO}_{3}^{-}-\mathrm{SO}_{4}^{2-}$ system, while AIM-II treats $\mathrm{NH}_{4}^{+}-\mathrm{NO}_{3}^{-}-\mathrm{SO}_{4}^{2-}$. For AIM, measured cations not treated by the model were accounted for as equivalent sodium $\left(\mathrm{Na}^{*}\right)$ in AIM-IV and equivalent ammonium $\left(\mathrm{NH}_{4}^{*}\right)$ in AIM-II. $\mathrm{Cl}^{-}$was accounted for as equivalent sulfate $\left(\mathrm{SO}_{4}{ }^{*}\right)$ in AIM-II. Ion balance is required for all simulations in E-AIM: any cation deficit was balanced using $\mathrm{H}^{+}$, while any anion deficit was balanced using $\mathrm{OH}^{-}$since these are also required model inputs. E-AIM assumes that $\mathrm{OH}^{-}$ balances any excess cations, rather than carbonate, and thus has regions of higher predicted aerosol $\mathrm{pH}$ compared with ISORROPIA.

E-AIM model runs were performed in solid + liquid mode where salts precipitate once the aqueous solution becomes saturated. Overall, strong similarities between E-AIM and
ISORROPIA suggest that the choice of metastable vs. stable (solid + liquid) mode did not appreciably affect the predicted aerosol $\mathrm{pH}$ levels. Given the importance of aerosol liquid water, data below $40 \%$ RH were excluded from the analysis. During the MILAGRO study, this was approximately $50 \%$ of the total measurement period. Further, points above $40 \%$ RH with modeled aerosol liquid water content of 0 were excluded from the analysis since a $\mathrm{pH}$ cannot be derived for these samples. This was the cause of differences in sample numbers between the E-AIM and ISORROPIA simulations (Table 2).

\section{Results and discussion}

\subsection{Thermodynamic equilibrium models}

Thermodynamic equilibrium models are frequently used to estimate aerosol acidity. Prior studies have observed and discussed large differences in aerosol acidity predicted by different models (Ansari and Pandis, 1999; Yao et al., 2006); we do not revisit this analysis but instead seek to understand some of the limitations and uncertainties of using thermodynamic equilibrium models to predict aerosol $\mathrm{pH}$. Figure 1 shows that a large source of uncertainty is tied to the availability of gas-phase data and whether the model is run in the forward (gas + aerosol inputs) or reverse (aerosol inputs only) mode. Note that the number of forward-mode predictions was less than the reverse-mode predictions due to availability of coincident aerosol- and gas-phase measurements. For ISORROPIA and E-AIM, the median differences between the models run in forward and reverse modes were 3.5 and $3.1 \mathrm{pH}$ units, respectively. This finding is consistent with a modeling study of aerosol $\mathrm{pH}$ in Hong Kong as well (Yao et al., 2006). Other parameters, such as aerosol liquid water, have much closer agreement between the forward and reverse modes (not shown), given that it is largely driven by total aerosol mass and, thus, is much less sensitive to gasphase species.

The large differences in the forward- and reverse-mode predictions of aerosol $\mathrm{pH}$ seen in Fig. 1 come about for several reasons. Upon specification of the aerosol species and surrounding $\mathrm{RH}$ and $T$, thermodynamic models first determine the aerosol $\mathrm{pH}$ and liquid water content (assuming that a liquid phase can exist), followed by computing the concentration of gas-phase semi-volatile compounds in equilibrium with the aerosol (e.g., $\mathrm{NH}_{3}, \mathrm{HNO}_{3}$, and $\mathrm{HCl}$ ). The aerosol $\mathrm{pH}$ is largely driven by electroneutrality in the aqueous phase, as any imbalance between charges from cations and anions needs to be balanced by $\mathrm{H}^{+}$and $\mathrm{OH}^{-}$:

$$
\left[\mathrm{H}^{+}\right]+\sum_{n+}\left[X^{+}\right]=\left[\mathrm{OH}^{-}\right]+\sum_{n-}\left[Y^{-}\right]
$$

or $\left[\mathrm{H}^{+}\right]+I_{\mathrm{b}}-\left[\mathrm{OH}^{-}\right]=0$,

where $I_{\mathrm{b}}=\sum_{n+}\left[X^{+}\right]-\sum_{n-}\left[Y^{-}\right]$is the ion balance parameter; $n^{+}$and $n^{-}$are the number of positively and nega- 


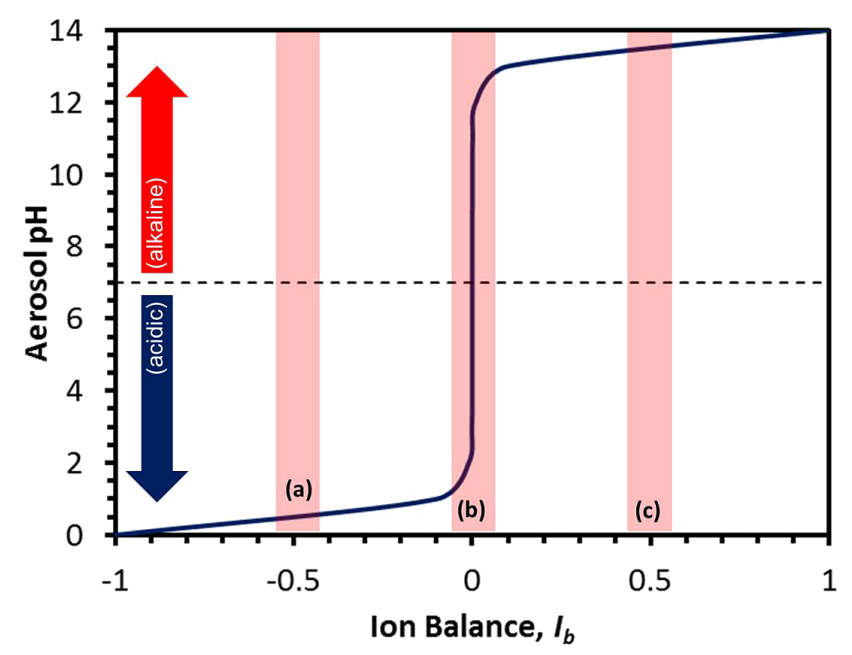

Figure 2. Aerosol $\mathrm{pH}$ as a function of the parameter $I_{\mathrm{b}}$ (see Eq. 7 for explanation). The data used here are hypothetical: values of $I_{\mathrm{b}}$ ranging from -1 to 1 at a constant aerosol loading were input under conditions of constant $T$ and RH to demonstrate the extreme sensitivity of aerosol $\mathrm{pH}$ at $I_{\mathrm{b}}$ values near 0.0 (region $\mathrm{b}$ ).

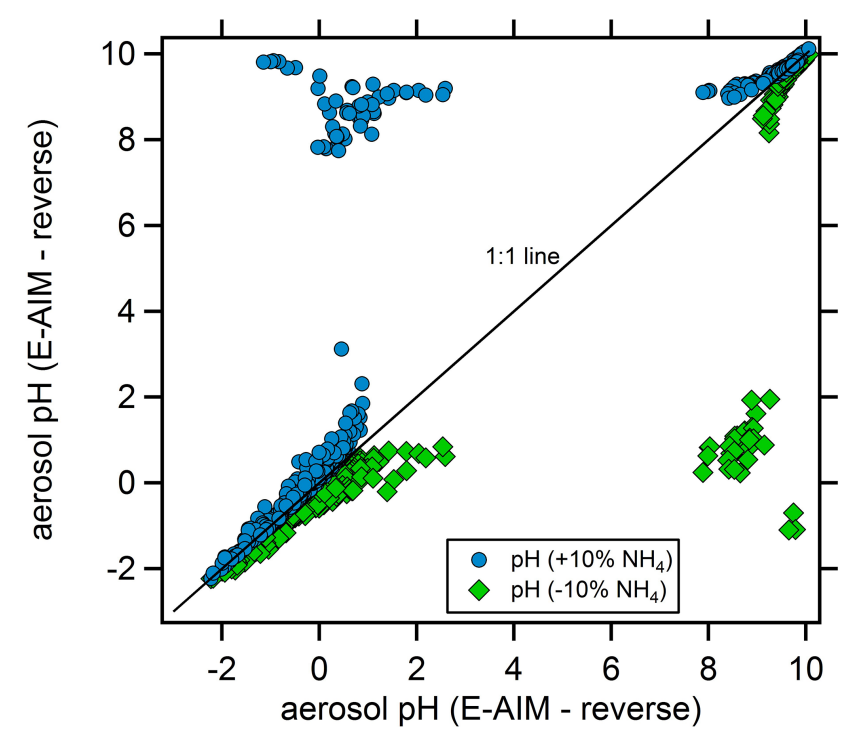

Figure 3. Sensitivity of aerosol pH predicted with E-AIM (reverse mode) to small changes in the input aerosol $\mathrm{NH}_{4}^{+}$concentration.

tively charged ionic species, respectively; and $\left[X^{+}\right]$is the concentration of a species in the aqueous phase, in gram equivalents (geq). In the case where the aerosol is acidic (i.e., $\mathrm{pH}<7$ or $I_{\mathrm{b}}<-\sqrt[2]{K_{\mathrm{w}}}$, with $K_{\mathrm{w}}=\left[\mathrm{OH}^{-}\right]\left[\mathrm{H}^{+}\right]$), $\left[\mathrm{OH}^{-}\right]$contributes negligibly to $I_{\mathrm{b}}$, and $\left[\mathrm{H}^{+}\right] \cong-I_{\mathrm{b}}$. Similarly, when the aerosol is alkaline (i.e., $\mathrm{pH}>7$ or $I_{\mathrm{b}}>\sqrt[2]{K_{\mathrm{w}}}$ ), $\left[\mathrm{H}^{+}\right]$contributes negligibly to $I_{\mathrm{b}},\left[\mathrm{OH}^{-}\right] \cong I_{\mathrm{b}}$, and $\left[\mathrm{H}^{+}\right]=$ $K_{\mathrm{w}} /\left[\mathrm{OH}^{-}\right]$.

Given the above, one can construct a diagram that relates aerosol $\mathrm{pH}$ to $I_{\mathrm{b}}$; this is shown in Fig. 2. It is noteworthy that
$\mathrm{pH}$ changes considerably over a narrow range of $I_{\mathrm{b}}$, when the value of $I_{\mathrm{b}}$ is close to 0 . For acidic and very alkaline aerosol, uncertainty in $I_{\mathrm{b}}$ - shown as the (a) and (c) regions of Fig. 2 - may introduce a $0.5-1.0 \mathrm{pH}$ unit bias in predicted $\mathrm{pH}$. In region (b), however, a small uncertainty in $I_{\mathrm{b}}$ leads to shifts in $\mathrm{pH}$ that span effectively $10 \mathrm{pH}$ units (or more). This uncertainty may come from either uncertainty in the measurements, themselves, or from approximations such as the exclusion of minor species (e.g., crustal elements) from the analysis. The data used in Fig. 2 are hypothetical: values of $I_{\mathrm{b}}$ ranging from -1 to 1 at a constant aerosol loading were input under conditions of constant $T$ and $\mathrm{RH}$ to generate the predicted pH. However, Fig. 3 shows that for the MILAGRO data set, the predicted aerosol $\mathrm{pH}$ (reverse mode) is extremely sensitive to minor uncertainties in the measurement inputs and, thus, to uncertainties in $I_{\mathrm{b}}$. Figure 3 shows the sensitivity in predicted aerosol $\mathrm{pH}$ under the reverse-mode calculation to $\pm 10 \%$ changes in the aerosol $\mathrm{NH}_{4}^{+}$concentration. The aerosol $\mathrm{pH}$ differed by more than $1.0 \mathrm{pH}$ unit for $18 \%$ of the data when $\mathrm{NH}_{4}^{+}$increased by $10 \%$. Likewise, aerosol $\mathrm{pH}$ differed by more than $1.0 \mathrm{pH}$ unit for $12 \%$ of the data when $\mathrm{NH}_{4}^{+}$decreased by $10 \%$. Similar sensitivities were also observed for $\pm 10 \%$ changes in aerosol $\mathrm{NO}_{3}^{-}$and $\mathrm{SO}_{4}^{2-}$ inputs. Using gas + aerosol inputs strongly constrains the effects of measurement errors and therefore is thought to give a more accurate representation of aerosol partitioning and composition (Fountoukis et al., 2009; Guo et al., 2014). Our results support this thought and indicate that reverse-mode calculations of aerosol $\mathrm{H}^{+}$and $\mathrm{pH}$ should likely be avoided for the interpretation of experimental data. The exception to this recommendation would be a system that contains very low concentrations of semi-volatiles. Without accompanying gasphase data to constrain the thermodynamic models, an alternate approach that may yield a more accurate representation of aerosol $\mathrm{pH}$ is the use of aerosol concentrations as input in forward-mode calculations. In the southeastern US, Guo et al. (2014) report that this approach led to biases in aerosol $\mathrm{pH}$ of $\sim 1 \mathrm{pH}$ unit, which is considerably lower than the bias observed in Fig. 1 if we assume that the forward-mode predictions are accurate (see more discussion on this point below).

\subsection{Phase partitioning}

Figure 4 shows aerosol $\mathrm{pH}$ predicted by ammonia phase partitioning vs. aerosol $\mathrm{pH}$ predicted by E-AIM and ISORROPIA run in the forward and reverse modes. To predict aerosol $\mathrm{pH}$ from the $\mathrm{NH}_{3} / \mathrm{NH}_{4}^{+}$phase equilibrium (Eq. 6), aerosol liquid water was taken from the forward model output of ISORROPIA. The temperature-dependent $K_{\mathrm{H}}$ and $K_{\mathrm{b}}$ are from Chameides (1984), while the temperaturedependent $K_{\mathrm{w}}$ is from Stumm and Morgan (1996). We have used liquid concentrations, not activities in the application of Eq. (6) (i.e., activity coefficients for $\mathrm{H}^{+}$and $\mathrm{NH}_{4}^{+}$are assumed to be unity), following the approach of Keene 

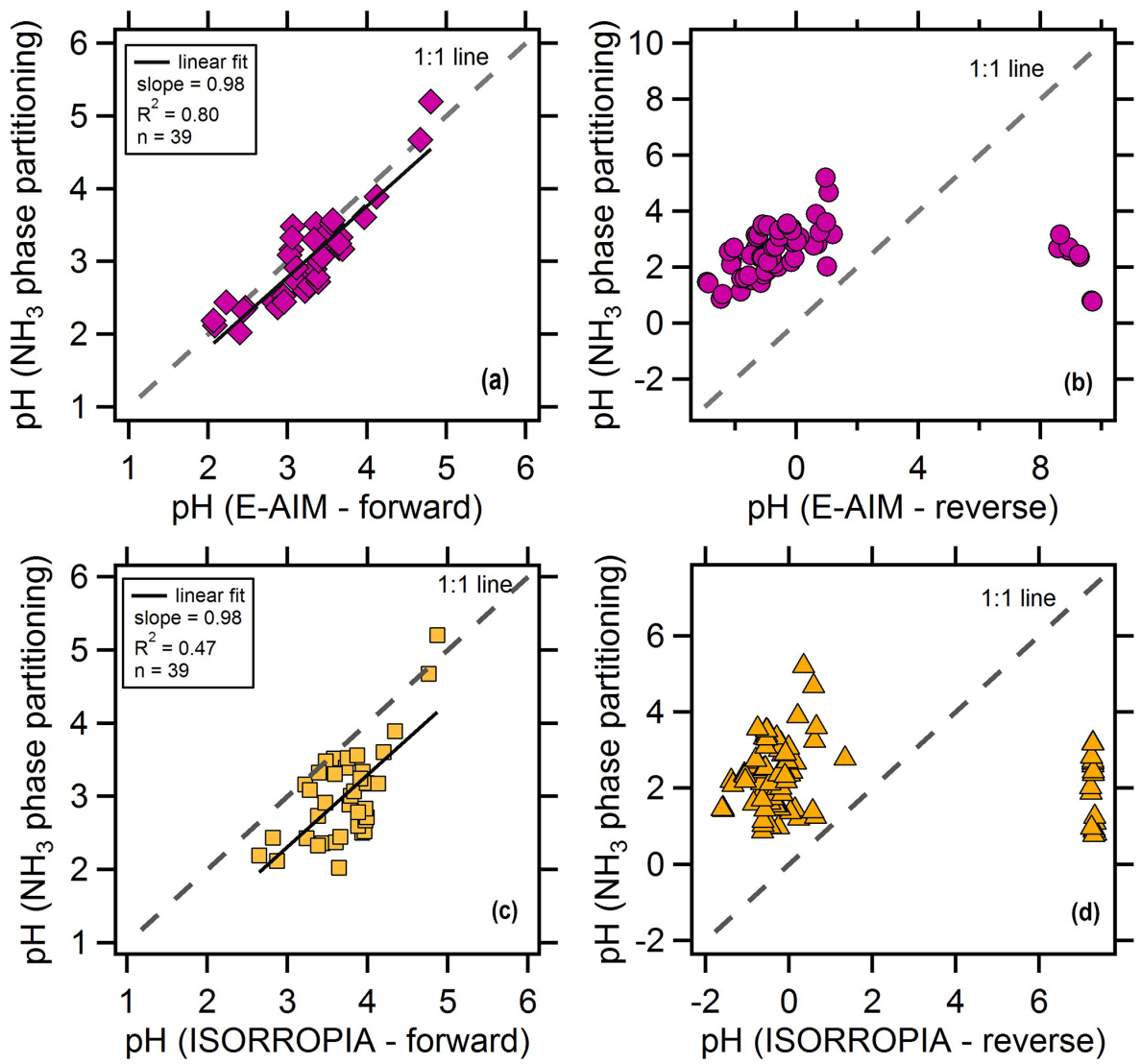

Figure 4. Aerosol pH predicted by the phase partitioning of ammonia compared to $\mathrm{pH}$ predicted by (a) E-AIM in the forward mode, (b) E-AIM in the reverse mode, (c) ISORROPIA in the forward mode, and (d) ISORROPIA in the reverse mode.

et al. (2004). The implications of these assumptions are discussed below. The best agreement between the phasepartitioning approach and the models was found for both forward model applications (Fig. 4a and c). A slope of 0.98 and high $R^{2}$ value (0.80) indicate excellent agreement between E-AIM and the phase-partitioning approach (Fig. 4a). The median difference between these methods was only $0.4 \mathrm{pH}$ unit. Likewise, good agreement was observed between ISORROPIA-II in the forward mode and the phasepartitioning pH (Fig. 4c, slope $=0.98$ and $R^{2}=0.47$ ).

Differences between the $\mathrm{NH}_{3} / \mathrm{NH}_{4}^{+}$phase-partitioning predictions and either thermodynamic model are possibly due to differences in equilibrium constants and/or differences in the activity coefficients, although the former is more likely. That is evident from the strong agreement seen in Fig. 4a; since E-AIM employs activity coefficient calculations for all species, our calculation using concentrations instead of activities does not appear to systematically bias the phasepartitioning $\mathrm{pH}$ predictions. A detailed characterization of uncertainties and sensitivities of the various methods to differences in equilibrium constants and activity coefficients is beyond the scope of this study but should be explored in the future.
The above results were contrasted by very poor agreement between the reverse models and phase-partitioning predictions of aerosol $\mathrm{pH}$ (Fig. $4 \mathrm{~b}$ and d). The median difference between aerosol $\mathrm{pH}$ predicted by $\mathrm{NH}_{3}$ phase partitioning and E-AIM run in the reverse mode was $3.5 \mathrm{pH}$ units $(n=72)$. Similarly, the median difference between aerosol $\mathrm{pH}$ predicted by $\mathrm{NH}_{3}$ phase partitioning and ISORROPIA-II run in reverse mode was $3.1 \mathrm{pH}$ units $(n=72)$. These large differences are consistent with the large differences observed between the forward and reverse predictions of $\mathrm{pH}$ (Fig. 1). These results are also consistent with large discrepancies (on the order of $1-4 \mathrm{pH}$ units) in aerosol $\mathrm{pH}$ between E-AIM run in the reverse mode and the phase-partitioning approach for a study in Hong Kong (Yao et al., 2006). As discussed above, gas + aerosol inputs constrain the effects of measurement uncertainty on thermodynamic models, and thus the large differences observed in Fig. $4 \mathrm{~b}$ and d provide further support that the reverse model applications are challenged to accurately predict aerosol $\mathrm{pH}$. For the MILAGRO data set, approximately half of all reverse model runs predicted $\mathrm{pH}$ values less than 0 (44\% for E-AIM, $51 \%$ for ISORROPIA). This is inconsistent with the observed aerosol ammonium fraction $\left(\mathrm{NH}_{4}^{+} /\left(\mathrm{NH}_{3}+\mathrm{NH}_{4}^{+}\right)\right)$, which was only 

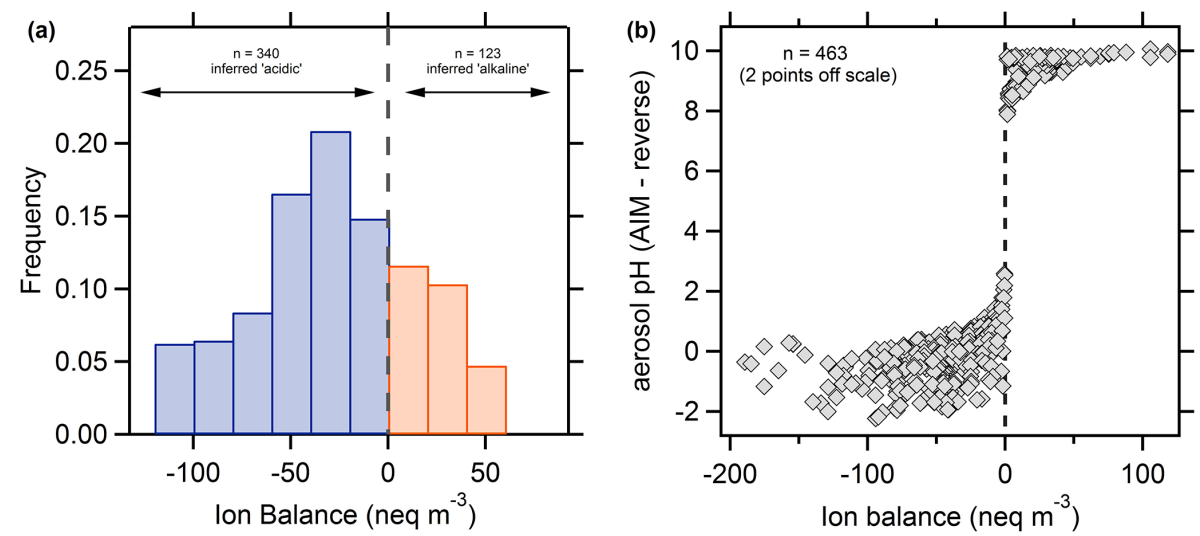

Figure 5. (a) Frequency distribution of the aerosol ion balance during MILAGRO, and (b) aerosol pH predicted by E-AIM in the reverse mode vs. the ion balance. The dashed lines at 0 serve as a visual reference for neutral particles.

0.2 , on average, over the study period. Under conditions typical of the MILAGRO study $\left(293 \mathrm{~K}, 10 \mu \mathrm{g} \mathrm{m}^{-3}\right.$ aerosol liquid water, total $\mathrm{NH}_{3}$ of $10-30 \mu \mathrm{g} \mathrm{m}^{-3}$ ), if the aerosol $\mathrm{pH}$ is less than 0 , thermodynamic calculations predict that essentially all of the $\mathrm{NH}_{3}$ will partition to the particle phase at equilibrium. The fact that gas-phase $\mathrm{NH}_{3}$ was abundant (Table 1) suggests either that (1) the system is not at equilibrium or that (2) aerosol $\mathrm{pH}>0$. Fountoukis et al. (2009) found that the equilibration timescales for $\mathrm{NH}_{3} / \mathrm{NH}_{4}^{+}$(approximately $10 \mathrm{~min}$ ) were on par with the measurement integration timescales during MILAGRO, strongly suggesting that the assumption of equilibrium is valid. This further supports the conclusion above that the reverse-mode models vastly overstate the acidity (underestimate $\mathrm{pH}$ ) of the Mexico City aerosol.

These results suggest that the two best proxy methods for estimating aerosol $\mathrm{pH}$ are (1) thermodynamic equilibrium models run using gas + aerosol inputs, and (2) the phase partitioning of ammonia. Under certain conditions, the phase partitioning of $\mathrm{HNO}_{3} / \mathrm{NO}_{3}^{-}$gives similar results to that of ammonia (Young et al., 2013), so this is another feasible approach. It should be noted that Young et al. (2013) caution against the use of $\mathrm{HCl} / \mathrm{Cl}^{-}$partitioning to estimate $\mathrm{pH}$ on the basis of large (order of magnitude) uncertainty in the Henry's law constant for $\mathrm{HCl}$. It should also be noted that Keene et al. (2004) observed relatively poor agreement between $\mathrm{pH}$ predicted by ammonia and nitric acid phase partitioning. This may be due to the explicit treatment of activity coefficients (as was done by Young et al., 2013), or to differences in other factors, such as relative ammonia levels, since this can introduce major differences in thermodynamic model predictions (Ansari and Pandis, 1999). Other limitations of the phase-partitioning approach should be considered, depending on the environment. This includes long equilibration timescales for coarse particles and the presence of insoluble or partially soluble salts (Jacobson, 1999; Fridlind and Jacobson, 2000; Meng and Seinfeld, 1996).

\subsection{Ion balance vs. aerosol pH}

Figure 5a shows a probability distribution for the ion balance during MILAGRO. All of the measured inorganic species (Sect. 2.5) were included in the calculation according to Eq. (2), but dissociated organic acids were not included since they were not measured. Approximately $75 \%$ of the paired cation-anion measurements had a cation deficit and would thus be inferred as acidic according to the ion balance. Figure $5 \mathrm{~b}$ shows the aerosol $\mathrm{pH}$ predicted by E-AIM (reverse mode) vs. the inorganic ion balance. The data follow the traditional titration curve shape, with those points having a negative ion balance (anions > cations) all having predicted $\mathrm{pH}$ below 3.0 and points having a positive ion balance (cations $>$ anions) all having predicted $\mathrm{pH}$ above 7.8.

The ion balance proxy method assumes that conditions of high aerosol $\mathrm{H}^{+}$loading (in $\mathrm{nmol} \mathrm{m}^{-3}$ ) correspond to an aerosol distribution with a low (acidic) pH (e.g., Feng et al., 2012; Zhang et al., 2012a). Figure 6 shows the relationship between predicted aerosol $\mathrm{pH}$ and the $\mathrm{H}^{+}$concentration inferred from the ion balance. An anion deficit in the ion balance is assumed to be due to $\mathrm{OH}^{-}$(Eq. 2) - implying extremely low $\mathrm{H}^{+}$levels - so only data with a negative ion balance were included in this analysis $(n=340)$. Figure 6 shows no correlation at all between the $\mathrm{H}^{+}$loading and the predicted aerosol $\mathrm{pH}$ using either the forward (Fig. 6a) or reverse models (Fig. 6b). Note the differences in $\mathrm{pH}$ predicted by the forward and reverse models, as observed in Fig. 1. Numerous points in the lowest $\mathrm{H}^{+}$quartile have $\mathrm{pH}$ levels below the median $\mathrm{pH}$ of the upper $\mathrm{H}^{+}$quartile (Fig. 6b). Similarly, for a given $\mathrm{H}^{+}$loading, a wide $\mathrm{pH}$ range of $\sim 2-3 \mathrm{pH}$ units is typically predicted. This wide $\mathrm{pH}$ range is observed across all $\mathrm{H}^{+}$loadings, even at the high and low ends, because aerosol liquid water content and the $\mathrm{H}^{+}$activity coefficient can differ dramatically for a given $\mathrm{H}^{+}$level. The ion balance method is insensitive to either of these factors that are critical in determining aerosol pH (Eq. 1). Pathak et al. (2009) found a simi- 


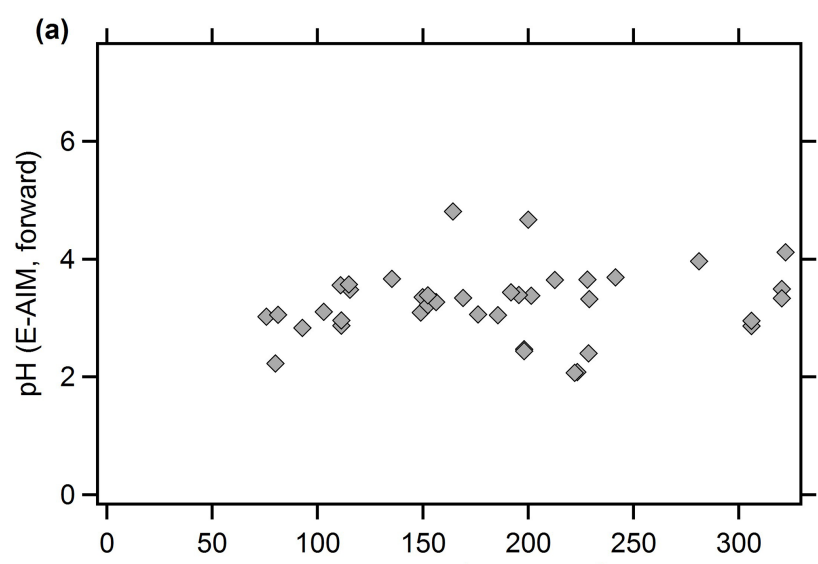

(b) Ion balance $\left[\mathrm{H}^{+}\right]\left(\mathrm{nmol} \mathrm{m}^{-3}\right)$

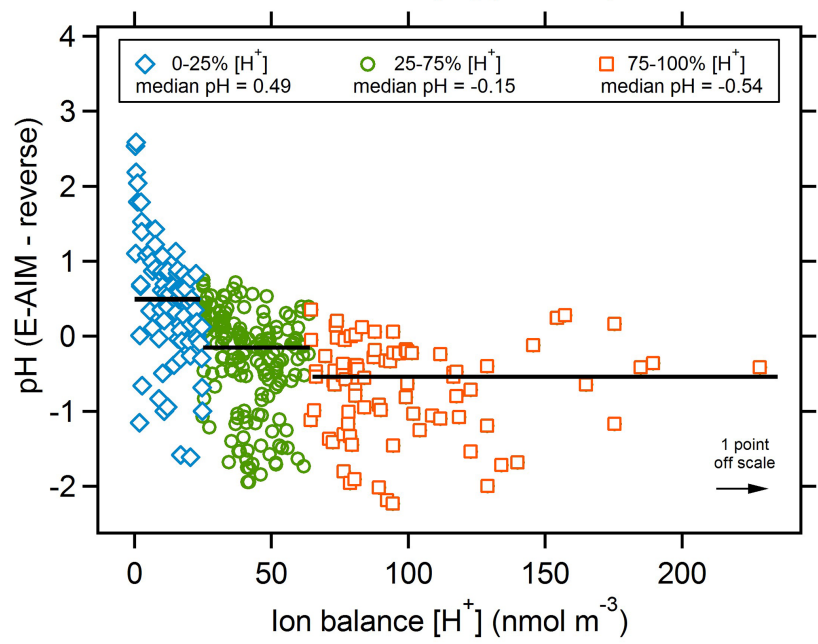

Figure 6. (a) Aerosol $\mathrm{pH}$ predicted by E-AIM in the forward mode vs. the $\mathrm{H}^{+}$concentration derived from the ion balance, and (b) aerosol $\mathrm{pH}$ predicted by E-AIM in the reverse mode vs. the $\mathrm{H}^{+}$concentration derived from the ion balance. Only points with a cation charge deficit $(\Sigma$ (anions) $>\Sigma$ (cations) $)$ are included in the analysis in (b). The horizontal black bars in (b) represent the medians corresponding to the values in the legend.

lar disconnect between $\mathrm{H}^{+}$inferred from the ion balance and predicted aerosol $\mathrm{pH}$ for measurements in four cities across China.

A further problem with the ion balance is that it is unable to distinguish between free and undissociated $\mathrm{H}^{+}$(e.g., protons associated with bisulfate $\left(\mathrm{HSO}_{4}^{-}\right)$); Keene et al., 2004). This limitation becomes very important when the solution $\mathrm{pH}$ approaches the $\mathrm{pK}_{\mathrm{a}}$ of any major ion that is associated with acidity, including $\mathrm{HNO}_{3}, \mathrm{HCl}$, and $\mathrm{NH}_{3}$. The $\mathrm{pK}_{\mathrm{a}}$ of $\mathrm{HSO}_{4}^{-}$ is 1.99 (Stumm and Morgan, 1996), and at $\mathrm{pH}$ levels below 3 the bisulfate-sulfate equilibrium begins to shift appreciably towards the protonated form, implying that the ion balance overestimates $\mathrm{H}^{+}$. This is illustrated in Fig. 7a and b, which shows the $\mathrm{H}^{+}$levels inferred from the ion balance compared to the $\mathrm{H}^{+}$loadings predicted by E-AIM and ISORROPIA (both run in reverse mode), respectively. Although the ther- modynamic models use electroneutrality to derive $\mathrm{H}^{+}$, they account for partial dissociation, which explains why the ion balance gives $\mathrm{H}^{+}$levels that are $\sim 45-65 \%$ higher than the models. The discrepancy in $\mathrm{pH}$ predicted by the forward- and reverse-mode thermodynamic calculations (Figs. 1 and 6) also implies large differences in the predicted aerosol $\mathrm{H}^{+}$ loadings. Figure $7 \mathrm{c}$ and $\mathrm{d}$ shows $\mathrm{H}^{+}$levels inferred from the ion balance compared to $\mathrm{H}^{+}$levels predicted by E-AIM and ISORROPIA, both run in forward mode. The forward-mode thermodynamic calculations predict $\mathrm{H}^{+}$levels that are orders of magnitude lower than either the ion balance or reversemode calculations, consistent with the large differences in predicted $\mathrm{pH}$ shown in Fig. 1. This is also consistent with large discrepancies in $\mathrm{H}^{+}$levels in Pittsburgh, PA, predicted by forward (Takahama et al., 2006) and reverse (Zhang et al., 2007) thermodynamic equilibrium model simulations. Although the measurement periods for these studies in Pittsburgh did not overlap, the similar $\mathrm{NH}_{4}^{+}$and $\mathrm{SO}_{4}^{2-}$ concentrations suggest that the large differences in aerosol $\mathrm{H}^{+}$were likely due to differences in the forward and reverse model simulations, not in the actual $\mathrm{pH}$ levels of the aerosol.

Finally, another major limitation in estimating the aerosol $\mathrm{H}^{+}$loading from the ion balance is high uncertainty in $\mathrm{H}^{+}$ that comes about from the propagation of measurement error. Figure $8 \mathrm{a}$ shows the relative ion balance uncertainty $(\%)$ vs. the ion balance loading $\left(\mathrm{nmol} \mathrm{m}^{-3}\right)$. Note that the points with a negative ion balance (orange trace in Fig. 8a) are inferred as the $\mathrm{H}^{+}$loading, and so this trace also represents the uncertainty in $\mathrm{H}^{+}$from the ion balance. The ion balance uncertainty was calculated using a standard propagation-oferror technique (Harris, 1999):

$$
\begin{aligned}
u_{\mathrm{IB}}= & \left(u_{\mathrm{Na}^{+}}^{2}+u_{\mathrm{NH}_{4}^{+}}^{2}+u_{\mathrm{Mg}^{2+}}^{2}+u_{\mathrm{Ca}^{2+}}^{2}+u_{\mathrm{K}^{+}}^{2}\right. \\
& \left.+u_{\mathrm{Cl}^{-}}^{2}+u_{\mathrm{NO}_{3}^{-}}^{2}+u_{\mathrm{SO}_{4}^{2-}}^{2}\right)^{\frac{1}{2}}
\end{aligned}
$$

where $u_{\mathrm{IB}}$ is the absolute uncertainty in the ion balance (in neq $\mathrm{m}^{-3}$ ), and the terms on the right-hand side represent the absolute uncertainties in each inorganic species in neq $\mathrm{m}^{-3}$ $\left(\mathrm{Na}^{+}, \mathrm{NH}_{4}^{+}, \mathrm{Mg}^{2+}, \mathrm{Ca}^{2+}, \mathrm{K}^{+}, \mathrm{Cl}^{-}, \mathrm{NO}_{3}^{-}\right.$, and $\left.\mathrm{SO}_{4}^{2-}\right)$, calculated assuming $10 \%$ relative uncertainty for each species. Figure 8a shows that the relative ion balance (and $\left[\mathrm{H}^{+}\right]$) uncertainty $\left(u_{\mathrm{IB}} /[\right.$ ion balance $\left.]\right)$ grows with decreasing ion balance or $\left[\mathrm{H}^{+}\right]$, as one would expect. A frequency distribution of the ion balance uncertainty from the MILAGRO study shows that approximately $40 \%$ of the ion balance and $\left[\mathrm{H}^{+}\right]$ calculations had an associated uncertainty higher than $50 \%$, and more than $20 \%$ of the ion balance and $\left[\mathrm{H}^{+}\right]$calculations had an associated uncertainty higher than $100 \%$ (Fig. 8b).

These results demonstrate numerous problems with the ion balance and strongly suggest that it is inadequate to represent the $\mathrm{pH}$ of atmospheric particles. The ion balance may provide a qualitative indication of acidic conditions when anions far exceed cations, but the variable effects of liquid water, the buffering action of $\mathrm{HSO}_{4}^{-} / \mathrm{SO}_{4}^{2-}$, and the effect of species 

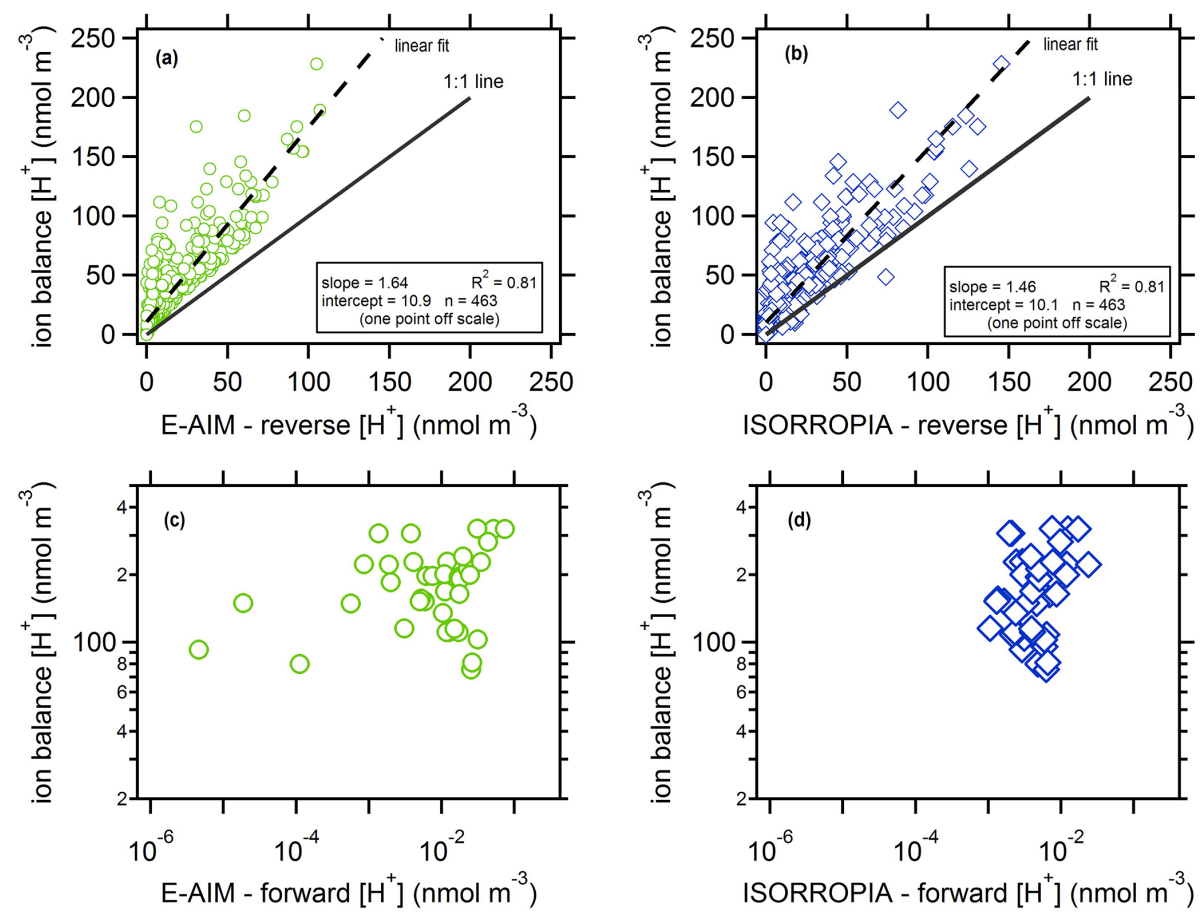

Figure 7. $\mathrm{H}^{+}$levels inferred from the ion balance compared to $\mathrm{H}^{+}$levels predicted by (a) E-AIM in the reverse mode, (b) ISORROPIA in the reverse mode, (c) E-AIM in the forward mode, and (d) ISORROPIA in the forward mode. Note the different log scales for the $x$ and $y$ axes in (c) and (d).
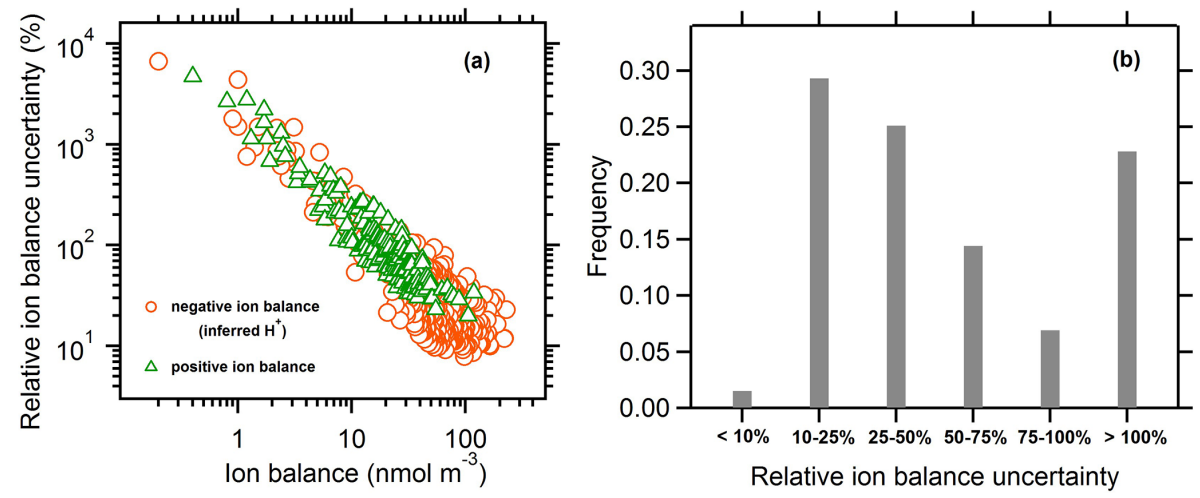

Figure 8. (a) Relative ion balance uncertainty $(\%)$ as a function of the ion balance level. Note that the orange trace represents $\left[\mathrm{H}^{+}\right]$, and so this trace also represents the uncertainty in $\left[\mathrm{H}^{+}\right]$from the ion balance. (b) Frequency distribution in the relative ion balance uncertainty.

activity coefficients in concentrated particles preclude its use for any quantitative means. Even when all ionic components - including the dissociated ions of organic acids - are accounted for and measured with good precision, the ion balance is unlikely to qualitatively distinguish alkaline particles from mildly acidic particles due to the propagation of uncertainties in the aerosol composition measurements. This recommendation against the use of the ion balance as a proxy for aerosol $\mathrm{pH}$ is supported by prior work (Keene and Savoie, 1998; Winkler, 1986; Guo et al., 2014). The $\mathrm{H}^{+}$concentration derived from the ion balance is often just a surrogate for sulfate, especially in environments where sulfate is the dominant inorganic species (Pathak et al., 2009; Zhang et al., 2007). It is possible - likely even - to simultaneously have particles with a low concentration of $\mathrm{H}^{+}$(in $\mathrm{nmol} \mathrm{m}^{-3}$ ) that are highly acidic (low $\mathrm{pH}$ ). Studies that infer the effects of particle acidity on atmospheric chemical processes using the inorganic ion balance are likely flawed. For example, correlations between SOA and aerosol $\mathrm{H}^{+}$concentrations from the ion balance have been interpreted as evidence of acidcatalyzed SOA formation (Feng et al., 2012; Budisulistiorini et al., 2013; Pathak et al., 2011; Nguyen et al., 2014; Zhang et 


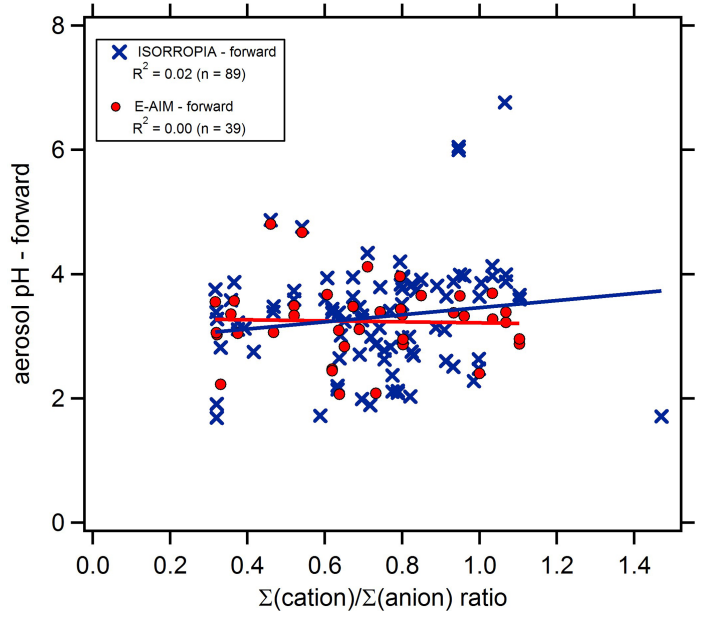

Figure 9. Aerosol $\mathrm{pH}$ predicted by the forward-mode equilibrium models compared to the $\Sigma$ (cations) $/ \Sigma$ (anions) charge ratio.

al., 2012a). These studies may have misinterpreted their data, since sulfate may actually be a limiting factor in isoprene and monoterpene SOA formation (Xu et al., 2015). $\mathrm{H}^{+}$derived from the ion balance is a surrogate for sulfate, and many factors lead to correlations between sulfate and SOA in regional pollution (Sun et al., 2011; Zhang et al., 2012b).

\subsection{Molar ratio vs. $\mathrm{pH}$}

Similar to applications of the ion balance, the molar ratio is frequently used as a proxy for aerosol $\mathrm{pH}$. Molar ratios that yield a charge balance (i.e., equivalence ratios of unity or greater) are assumed for fully neutralized aerosol, while decreasing cation / anion ratios are assumed to represent decreasing aerosol pH (He et al., 2012; Kerminen et al., 2001; Huang et al., 2013). The data and assumptions that underlie the molar ratio method are the same as those used to calculate the ion balance. Thus, many of the same limitations apply to the molar ratio method. The exclusion of minor ionic species, including crustal elements and dissociated organic acids, can significantly bias the results (Cao et al., 2013; Jacobson, 1999; Trebs et al., 2005; Ziemba et al., 2007; Moya et al., 2002). The propagation of analytical uncertainty can also create problems with the signal-to-noise ratio for many samples that will challenge the interpretations of the molar ratio. Finally, the molar ratio does not account for the effects of aerosol water or species activities on particle acidity. Given the similar assumptions and limitations, it should be unsurprising that $\left[\mathrm{H}^{+}\right]$from the ion balance was highly correlated with the cation / anion molar ratio $\left(R^{2}=0.66\right.$, not shown) for the MILAGRO data set. Similar to the ion balance results, no correlation was observed between the molar ratio and forward-mode predictions of aerosol pH (Fig. 9). Zhang et al. (2007) and Behera et al. (2014) demonstrated similar problems translating the molar ratio into aerosol $\mathrm{pH}$ for studies in Pittsburgh and Singapore, respectively. Even

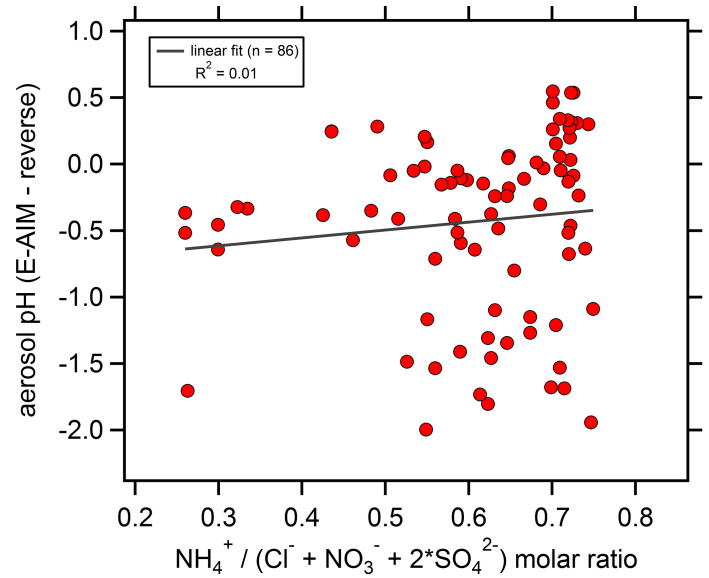

Figure 10. Predicted aerosol $\mathrm{pH}$ vs. the $\mathrm{NH}_{4}^{+} /\left(\mathrm{Cl}^{-}+\mathrm{NO}_{3}^{-}+\right.$ $2^{*} \mathrm{SO}_{4}^{2-}$ ) molar ratio, using only data where the ratio is less than 0.75 (region inferred as highly acidic) and where $\Sigma\left(\mathrm{NH}_{4}^{+}+\mathrm{Cl}^{-}+\right.$ $\mathrm{NO}_{3}^{-}+\mathrm{SO}_{4}^{2-}$ ) accounts for greater than $95 \%$ of measured inorganic aerosol mass (i.e., with low crustal concentrations).

under the limiting case when (1) crustal elements were low (where $\mathrm{NH}_{4}^{+}, \mathrm{Cl}^{-}, \mathrm{NO}_{3}^{-}$, and $\mathrm{SO}_{4}^{2-}$ together accounted for greater than $95 \%$ of inorganic aerosol ion mass) and (2) the aerosol regime was inferred to be highly acidic (samples with $\mathrm{NH}_{4}^{+} /\left(\mathrm{Cl}^{-}+\mathrm{NO}_{3}^{-}+2^{*} \mathrm{SO}_{4}^{2-}\right)$ molar ratios less than 0.75), there was no correlation between the molar ratio and predicted pH (Fig. 10).

These results indicate that the molar ratio is not a suitable proxy to infer the acidity of atmospheric particles. This applies to all variations of the molar ratio (Eqs. 3, 4, or 5). When the majority of inorganic species (>95\%) are accounted for, the molar ratio is able to distinguish alkaline particles from acidic particles with good reliability; however, it is unable to provide any measure - even qualitative - of the degree of aerosol acidity. The lack of relationship between the molar ratio and predicted aerosol $\mathrm{pH}$ strongly suggests problems with studies that have used the molar ratio as a proxy for $\mathrm{pH}$. For example, studies that have attempted to characterize the occurrence of acid-catalyzed SOA formation in the atmosphere may have incorrectly interpreted the aerosol acidity using a molar ratio approach (e.g., Tanner et al., 2009; Peltier et al., 2007; Zhang et al., 2007; Froyd et al., 2010).

\section{Conclusions}

We have carried out an analysis of proxy methods used to estimate the $\mathrm{pH}$ of atmospheric particles. The ion balance method, which is used to infer the aerosol $\mathrm{H}^{+}$loading, showed no correlation with aerosol $\mathrm{pH}$ predicted by multiple independent metrics. This indicates that conditions of increasing $\mathrm{H}^{+}$loading do not necessarily correspond to decreasing (i.e., more acidic) aerosol $\mathrm{pH}$. Likewise, the cation/anion molar ratio (and related metrics) showed no 
relationship with different predictions of aerosol $\mathrm{pH}$. When species accounting for greater than $95 \%$ of inorganic aerosol mass were included in the analysis, the molar ratio appears to reliably distinguish acidic from alkaline particles; however, the molar ratio should not be treated as a surrogate for aerosol $\mathrm{pH}$. The molar ratio actually showed a strong relationship with the ion balance. A major reason for the inability of these methods to represent aerosol $\mathrm{pH}$ is that both neglect the effects of aerosol water and partial dissolution of ions and acids on $\mathrm{pH}$, in accordance with previously published studies (Keene and Savoie, 1998; Winkler, 1986). Further, the ion balance and molar ratio can also be severely limited by signal-to-noise ratio due to analytical uncertainties. These results strongly discourage the use of the ion balance or molar ratio for $\mathrm{pH}$ or $\mathrm{H}^{+}$inference.

These results also suggest that thermodynamic equilibrium models require both gas + aerosol inputs for accurate predictions of $\mathrm{H}^{+}$and $\mathrm{pH}$. Two independent models - E-AIM and ISORROPIA - performed similarly and predict much lower $\mathrm{pH}$ (more acidic particles) in the reverse modes using aerosol inputs only. The aerosol $\mathrm{pH}$ levels predicted by both reverse models do not agree with either the $\mathrm{pH}$ predictions using gas + aerosol inputs or the phase partitioning of ammonia. The models in reverse mode predict highly acidic particles for extended periods of time (i.e., $\mathrm{pH}<0$ ), despite high concentrations of gas-phase ammonia and relatively short equilibration timescales. Further, the models in reverse mode are highly sensitive to uncertainty in the measurement inputs: small deviations in major aerosol species on the order of common aerosol measurement uncertainties can induce changes in predicted $\mathrm{pH}$ that exceed $10 \mathrm{pH}$ units. This recommendation is consistent with other studies that show much better model performance when aerosol + gas inputs are used (Fountoukis et al., 2009; Guo et al., 2014).

Thermodynamic equilibrium models in forward mode had very good agreement with $\mathrm{pH}$ predicted by the phase partitioning of ammonia. These methods are largely, but not completely, independent, as the aerosol liquid water required for the phase-partitioning calculation is obtained from the same thermodynamic models. In addition, the use of activity coefficients from thermodynamic models as inputs in the phase-partitioning calculations would further couple the two methods. This has been avoided in the present analysis by using concentrations instead of activities. Thermodynamic equilibrium models are generally quite skilled in predicting aerosol liquid water (Khlystov et al., 2005), so this likely introduces minimal uncertainty to the present analysis. In regions where organics are high, their contribution to aerosol liquid water (and hence $\mathrm{pH}$ ) should be investigated (Guo et al., 2014). The fact that these largely independent methods agreed so closely provides the basis for the recommendation of their use to estimate the $\mathrm{pH}$ of atmospheric particles. As with the application of thermodynamic equilibrium models, the phase-partitioning approach makes the implicit assumption that the gas/particle system is at equilibrium. This appears to be a good assumption for the Mexico City data set (Fountoukis et al., 2009), but it can be a poor assumption when coarse particles are abundant, such as in the marine environment (Fridlind and Jacobson, 2000). The phasepartitioning approach is also likely limited in ammonia-poor environments where all or most of the ammonia resides in the aerosol phase. In such environments, the phase partitioning of nitric acid may be a good alternative if both nitric acid and aerosol nitrate concentrations are high enough (Young et al., 2013; Meskhidze et al., 2003). Uncertainty in the Henry's law constant of other compounds, especially $\mathrm{HCl}$, may limit the application of the phase-partitioning approach beyond $\mathrm{NH}_{3} / \mathrm{NH}_{4}^{+}$and $\mathrm{HNO}_{3} / \mathrm{NO}_{3}^{-}$(Young et al., 2013).

Our recommendation for the use of the phase-partitioning approach and forward equilibrium model calculations to best predict aerosol $\mathrm{pH}$ contradicts the recommendations in a similar study (Yao et al., 2006). Both our study (from Mexico City) and the Yao et al. (2006) study (Hong Kong) agree that E-AIM run in the reverse mode yields predicted aerosol $\mathrm{pH}$ levels significantly lower than the phase partitioning or forward model predictions. We differ in our interpretation of the results: Yao et al. (2006) conclude that the phase-partitioning approach and forward model calculations erroneously assume that the gas-aerosol system has reached equilibrium, even though their analysis is based upon 12 and $24 \mathrm{~h} \mathrm{PM}_{2.5}$ measurements. This sampling time should far exceed the equilibration time for submicron particles, which is on the order of seconds to minutes (Meng and Seinfeld, 1996). In addition, our comparisons in Fig. $4 \mathrm{a}$ and c only include the subset of data where $\mathrm{RH}$ exceeds $60 \%$, a region in which the thermodynamic predictions - and assumption of equilibrium - become more accurate (Moya et al., 2002). Fountoukis et al. (2009) examined the equilibrium assumption for $\mathrm{PM}_{2.5}$ during MILAGRO and found it to be valid. Thus, we believe that the forward thermodynamic models and phasepartitioning approach are far more accurate in their predictions of $\mathrm{pH}$ than the reverse models run in closed mode without the additional constraint of gas-phase data.

These recommendations should be evaluated in other environments with different chemical characteristics and meteorology than was observed during MILAGRO. In particular, the recommendations should be evaluated in ammoniapoor environments, since thermodynamic equilibrium models often diverge in their predictions under such conditions (Ansari and Pandis, 1999). Despite their uncertainties, thermodynamic models and phase partitioning provide the best methods to estimate the $\mathrm{pH}$ of fine atmospheric particles. Other widely used metrics - ion balance and ion ratios - are misleading and should be avoided beyond the establishment of general alkalinity or acidity. Hence, conclusions that are sensitive to aerosol $\mathrm{pH}$ but that are based upon the ion balance or molar ratio may need revision. 
Acknowledgements. The authors gratefully acknowledge the use of $\mathrm{NH}_{3}$ data from M. L. Fischer (Environmental Energy Technologies Division, Lawrence Berkeley National Laboratory) and $\mathrm{HNO}_{3}$ data from R. C. Cohen (Department of Chemistry, University of California, Berkeley) and D. K. Farmer (Department of Chemistry, Colorado State University). We also gratefully acknowledge useful conversations with J. G. Murphy (Department of Chemistry, University of Toronto). C. J. Hennigan acknowledges support from the NSF through award AGS-1464458. R. J. Weber acknowledges support from the NSF through award 1242258. A. Nenes acknowledges support from the EPA STAR program through award R835410, and from a Georgia Power Faculty Scholar Chair and Cullen-Peck Faculty Fellowship awarded by the Georgia Institute of Technology.

Edited by: A. Kiendler-Scharr

\section{References}

Ahrens, L., Harner, T., Shoeib, M., Lane, D. A., and Murphy, J. G.: Improved Characterization of Gas-Particle Partitioning for Perand Polyfluoroalkyl Substances in the Atmosphere Using Annular Diffusion Denuder Samplers, Environ. Sci. Technol., 46, 7199-7206, doi:10.1021/Es300898s, 2012.

Ansari, A. S. and Pandis, S. N.: An analysis of four models predicting the partitioning of semivolatile inorganic aerosol components, Aerosol. Sci. Tech., 31, 129-153, doi:10.1080/027868299304200, 1999.

Behera, S., Cheng, J., and Balasubramanian, R.: In situ acidity and $\mathrm{pH}$ of size-fractionated aerosols during a recent smokehaze episode in Southeast Asia, Environ. Geochem. Hlth., 1-17, doi:10.1007/s10653-014-9660-1, 2014.

Brown, S. S., Thornton, J. A., Keene, W. C., Pszenny, A. A. P., Sive, B. C., Dube, W. P., Wagner, N. L., Young, C. J., Riedel, T. P., Roberts, J. M., VandenBoer, T. C., Bahreini, R., Ozturk, F., Middlebrook, A. M., Kim, S., Hubler, G., and Wolfe, D. E.: Nitrogen, Aerosol Composition, and Halogens on a Tall Tower (NACHTT): Overview of a wintertime air chemistry field study in the front range urban corridor of Colorado, J. Geophys. Res.Atmos., 118, 8067-8085, doi:10.1002/Jgrd.50537, 2013.

Budisulistiorini, S. H., Canagaratna, M. R., Croteau, P. L., Marth, W. J., Baumann, K., Edgerton, E. S., Shaw, S. L., Knipping, E. M., Worsnop, D. R., Jayne, J. T., Gold, A., and Surratt, J. D.: Real-Time Continuous Characterization of Secondary Organic Aerosol Derived from Isoprene Epoxydiols in Downtown Atlanta, Georgia, Using the Aerodyne Aerosol Chemical Speciation Monitor, Environ. Sci. Technol., 47, 5686-5694, doi:10.1021/Es400023n, 2013.

Cao, J. J., Tie, X. X., Dabberdt, W. F., Jie, T., Zhao, Z. Z., An, Z. S., Shen, Z. X., and Feng, Y. C.: On the potential high acid deposition in northeastern China, J. Geophys. Res.-Atmos., 118, 4834-4846, doi:10.1002/Jgrd.50381, 2013.

Chameides, W. L.: The photochemistry of a remote marine stratiform cloud, J. Geophys. Res.-Atmos., 89, 4739-4755, 10.1029/JD089iD03p04739, 1984.

Clegg, S. L., Brimblecombe, P., and Wexler, A. S.: Thermodynamic model of the system $\mathrm{H}^{+}-\mathrm{NH}_{4}^{+}-\mathrm{SO}_{4}^{2-}-\mathrm{NO}_{3}^{-}-\mathrm{H}_{2} \mathrm{O}$ at tropospheric temperatures, J. Phys. Chem. A, 102, 2137-2154, doi:10.1021/Jp973042r, 1998.
Clegg, S. L., Seinfeld, J. H., and Edney, E. O.: Thermodynamic modelling of aqueous aerosols containing electrolytes and dissolved organic compounds. II. An extended ZdanovskiiStokes-Robinson approach, J. Aerosol Sci., 34, 667-690, doi:10.1016/s0021-8502(03)00019-3, 2003.

Day, D. A., Wooldridge, P. J., Dillon, M. B., Thornton, J. A., and Cohen, R. C.: A thermal dissociation laser-induced fluorescence instrument for in situ detection of $\mathrm{NO}_{2}$, peroxy nitrates, alkyl nitrates, and $\mathrm{HNO}_{3}$, J. Geophys. Res.-Atmos., 107, 4046, doi:10.1029/2001jd000779, 2002.

Dockery, D. W., Cunningham, J., Damokosh, A. I., Neas, L. M., Spengler, J. D., Koutrakis, P., Ware, J. H., Raizenne, M., and Speizer, F. E.: Health effects of acid aerosols on North American children: Respiratory symptoms, Environ. Health Persp., 104, 500-505, doi:10.2307/3432990, 1996.

Farmer, D. K., Perring, A. E., Wooldridge, P. J., Blake, D. R., Baker, A., Meinardi, S., Huey, L. G., Tanner, D., Vargas, O., and Cohen, R. C.: Impact of organic nitrates on urban ozone production, Atmos. Chem. Phys., 11, 4085-4094, doi:10.5194/acp-11-40852011, 2011.

Feng, J. L., Guo, Z. G., Zhang, T. R., Yao, X. H., Chan, C. K., and Fang, M.: Source and formation of secondary particulate matter in $\mathrm{PM}_{2.5}$ in Asian continental outflow, J. Geophys. Res.-Atmos., 117, D03302, doi:10.1029/2011jd016400, 2012.

Fountoukis, C. and Nenes, A.: ISORROPIA II: a computationally efficient thermodynamic equilibrium model for $\mathrm{K}^{+}$ $\mathrm{Ca}^{2+}-\mathrm{Mg}^{2+}-\mathrm{NH}_{4}^{+}-\mathrm{Na}^{+}-\mathrm{SO}_{4}^{2-}-\mathrm{NO}_{3}^{-}-\mathrm{Cl}^{-}-\mathrm{H}_{2} \mathrm{O}$ aerosols, Atmos. Chem. Phys., 7, 4639-4659, doi:10.5194/acp-7-4639-2007, 2007.

Fountoukis, C., Nenes, A., Sullivan, A., Weber, R., Van Reken, T., Fischer, M., Matías, E., Moya, M., Farmer, D., and Cohen, R. C.: Thermodynamic characterization of Mexico City aerosol during MILAGRO 2006, Atmos. Chem. Phys., 9, 2141-2156, doi:10.5194/acp-9-2141-2009, 2009.

Fridlind, A. M. and Jacobson, M. Z.: A study of gas-aerosol equilibrium and aerosol $\mathrm{pH}$ in the remote marine boundary layer during the First Aerosol Characterization Experiment (ACE 1), J. Geophys. Res.-Atmos., 105, 17325-17340, doi:10.1029/2000jd900209, 2000.

Froyd, K. D., Murphy, S. M., Murphy, D. M., de Gouw, J. A., Eddingsaas, N. C., and Wennberg, P. O.: Contribution of isoprene-derived organosulfates to free tropospheric aerosol mass, P. Natl. Acad. Sci. USA, 107, 21360-21365, doi:10.1073/pnas.1012561107, 2010.

Gaston, C. J., Riedel, T. P., Zhang, Z., Gold, A., Surratt, J. D., and Thornton, J. A.: Reactive Uptake of an Isoprene-derived Epoxydiol to Submicron Aerosol Particles, Environ. Sci. Technol., 48, 11178-11186, doi:10.1021/es5034266, 2014.

Guo, H., Xu, L., Bougiatioti, A., Cerully, K. M., Capps, S. L., Hite, J. R., Carlton, A. G., Lee, S.-H., Bergin, M. H., Ng, N. L., Nenes, A., and Weber, R. J.: Particle water and $\mathrm{pH}$ in the southeastern United States, Atmos. Chem. Phys. Discuss., 14, 27143-27193, doi:10.5194/acpd-14-27143-2014, 2014.

Gwynn, R. C., Burnett, R. T., and Thurston, G. D.: A time-series analysis of acidic particulate matter and daily mortality and morbidity in the Buffalo, New York, region, Environ. Health Persp., 108, 125-133, doi:10.2307/3454510, 2000.

Harris, D. C.: Quantitative Chemical Analysis, 5th Ed., edited by: Freeman, W. H. and Company, New York, 1999. 
He, K., Zhao, Q., Ma, Y., Duan, F., Yang, F., Shi, Z., and Chen, G.: Spatial and seasonal variability of $\mathrm{PM}_{2.5}$ acidity at two Chinese megacities: insights into the formation of secondary inorganic aerosols, Atmos. Chem. Phys., 12, 1377-1395, doi:10.5194/acp12-1377-2012, 2012.

Hennigan, C. J., Sullivan, A. P., Fountoukis, C. I., Nenes, A., Hecobian, A., Vargas, O., Peltier, R. E., Case Hanks, A. T., Huey, L. G., Lefer, B. L., Russell, A. G., and Weber, R. J.: On the volatility and production mechanisms of newly formed nitrate and water soluble organic aerosol in Mexico City, Atmos. Chem. Phys., 8, 3761-3768, doi:10.5194/acp-8-3761-2008, 2008.

Huang, Y., Li, L., Li, J., Wang, X., Chen, H., Chen, J., Yang, X., Gross, D. S., Wang, H., Qiao, L., and Chen, C.: A case study of the highly time-resolved evolution of aerosol chemical and optical properties in urban Shanghai, China, Atmos. Chem. Phys., 13, 3931-3944, doi:10.5194/acp-13-3931-2013, 2013.

Jacobson, M. Z.: Studying the effects of calcium and magnesium on size-distributed nitrate and ammonium with EQUISOLV II, Atmos. Environ., 33, 3635-3649, doi:10.1016/S13522310(99)00105-3, 1999.

Jang, M., Cao, G., and Paul, J.: Colorimetric particle acidity analysis of secondary organic aerosol coating on submicron acidic aerosols, Aerosol. Sci. Tech., 42, 409-420, doi:10.1080/02786820802154861, 2008.

Johnson, A. H., Moyer, A., Bedison, J. E., Richter, S. L., and Willig, S. A.: Seven Decades of Calcium Depletion in Organic Horizons of Adirondack Forest Soils, Soil Sci. Soc. Am. J., 72, 1824-1830, doi:10.2136/sssaj2006.0407, 2008.

Keene, W. C. and Savoie, D. L.: The $\mathrm{pH}$ of deliquesced sea-salt aerosol in polluted marine air, Geophys. Res. Lett., 25, 21812184, doi:10.1029/98g101591, 1998.

Keene, W. C., Sander, R., Pszenny, A. A. P., Vogt, R., Crutzen, P. J., and Galloway, J. N.: Aerosol pH in the marine boundary layer: A review and model evaluation, J. Aerosol Sci., 29, 339-356, doi:10.1016/S0021-8502(97)10011-8, 1998.

Keene, W. C., Pszenny, A. A. P., Maben, J. R., and Sander, R.: Variation of marine aerosol acidity with particle size, Geophys. Res. Lett., 29, 1101, doi:10.1029/2001g1013881, 2002.

Keene, W. C., Pszenny, A. A. P., Maben, J. R., Stevenson, E., and Wall, A.: Closure evaluation of size-resolved aerosol $\mathrm{pH}$ in the New England coastal atmosphere during summer, J. Geophys. Res.-Atmos., 109, D23307, doi:10.1029/2004jd004801, 2004.

Kerminen, V. M., Hillamo, R., Teinila, K., Pakkanen, T., Allegrini, I., and Sparapani, R.: Ion balances of size-resolved tropospheric aerosol samples: implications for the acidity and atmospheric processing of aerosols, Atmos. Environ., 35, 5255-5265, doi:10.1016/S1352-2310(01)00345-4, 2001.

Khlystov, A., Stanier, C. O., Takahama, S., and Pandis, S. N.: Water content of ambient aerosol during the Pittsburgh air quality study, J. Geophys. Res.-Atmos., 110, D07s10, doi:10.1029/2004jd004651, 2005.

Kim, Y. P., Seinfeld, J. H., and Saxena, P.: Atmospheric Gas Aerosol Equilibrium 1. Thermodynamic Model, Aerosol. Sci. Tech., 19, 157-181, doi:10.1080/02786829308959628, 1993.

Koutrakis, P., Wolfson, J. M., and Spengler, J. D.: An Improved Method for Measuring Aerosol Strong Acidity: Results from a Nine-month Study in St. Louis, Missouri and Kingston, Tennessee, Atmos. Environ., 22, 157-162, 1988.
Lawrence, J. and Koutrakis, P.: Measurement and speciation of gas and particulate phase organic acidity in an urban environment: 2. Speciation, J. Geophys. Res.-Atmos., 101, 9171-9184, doi:10.1029/95jd03357, 1996.

Likens, G. E., Driscoll, C. T., and Buso, D. C.: Long-term effects of acid rain: Response and recovery of a forest ecosystem, Science, 272, 244-246, doi:10.1126/science.272.5259.244, 1996.

Mahowald, N.: Aerosol Indirect Effect on Biogeochemical Cycles and Climate, Science, 334, 794-796, doi:10.1126/science.1207374, 2011.

Meng, Z. Y. and Seinfeld, J. H.: Time scales to achieve atmospheric gas-aerosol equilibrium for volatile species, Atmos. Environ., 30, 2889-2900, doi:10.1016/1352-2310(95)00493-9, 1996.

Meskhidze, N., Chameides, W. L., Nenes, A., and Chen, G.: Iron mobilization in mineral dust: Can anthropogenic $\mathrm{SO}_{2}$ emissions affect ocean productivity?, Geophys. Res. Lett., 30, 2085, doi:10.1029/2003g1018035, 2003.

Meskhidze, N., Chameides, W. L., and Nenes, A.: Dust and pollution: A recipe for enhanced ocean fertilization?, J. Geophys. Res.-Atmos., 110, D03301, doi:10.1029/2004jd005082, 2005.

Metzger, S., Mihalopoulos, N., and Lelieveld, J.: Importance of mineral cations and organics in gas-aerosol partitioning of reactive nitrogen compounds: case study based on MINOS results, Atmos. Chem. Phys., 6, 2549-2567, doi:10.5194/acp-6-25492006, 2006.

Molina, L. T., Madronich, S., Gaffney, J. S., Apel, E., de Foy, B., Fast, J., Ferrare, R., Herndon, S., Jimenez, J. L., Lamb, B., Osornio-Vargas, A. R., Russell, P., Schauer, J. J., Stevens, P. S., Volkamer, R., and Zavala, M.: An overview of the MILAGRO 2006 Campaign: Mexico City emissions and their transport and transformation, Atmos. Chem. Phys., 10, 8697-8760, doi:10.5194/acp-10-8697-2010, 2010.

Moya, M., Pandis, S. N., and Jacobson, M. Z.: Is the size distribution of urban aerosols determined by thermodynamic equilibrium? An application to Southern California, Atmos. Environ. 36, 2349-2365, doi:10.1016/S1352-2310(01)00549-0, 2002.

Nenes, A., Pandis, S. N., and Pilinis, C.: ISORROPIA: A new thermodynamic equilibrium model for multiphase multicomponent inorganic aerosols, Aquat. Geochem., 4, 123-152, doi:10.1023/a:1009604003981, 1998.

Nenes, A., Pandis, S. N., and Pilinis, C.: Continued development and testing of a new thermodynamic aerosol module for urban and regional air quality models, Atmos. Environ., 33, 15531560, doi:10.1016/S1352-2310(98)00352-5, 1999.

Nenes, A., Krom, M. D., Mihalopoulos, N., Van Cappellen, P., Shi, Z., Bougiatioti, A., Zarmpas, P., and Herut, B.: Atmospheric acidification of mineral aerosols: a source of bioavailable phosphorus for the oceans, Atmos. Chem. Phys., 11, 6265-6272, doi:10.5194/acp-11-6265-2011, 2011.

Nguyen, Q. T., Christensen, M. K., Cozzi, F., Zare, A., Hansen, A. M. K., Kristensen, K., Tulinius, T. E., Madsen, H. H., Christensen, J. H., Brandt, J., Massling, A., Nøjgaard, J. K., and Glasius, M.: Understanding the anthropogenic influence on formation of biogenic secondary organic aerosols in Denmark via analysis of organosulfates and related oxidation products, Atmos. Chem. Phys., 14, 8961-8981, doi:10.5194/acp-14-8961-2014, 2014. 
Paciga, A. L., Riipinen, I., and Pandis, S. N.: Effect of Ammonia on the Volatility of Organic Diacids, Environ. Sci. Technol., 48, 13769-13775, doi:10.1021/es5037805, 2014.

Pan, Y. P., Wang, Y. S., Tang, G. Q., and Wu, D.: Spatial distribution and temporal variations of atmospheric sulfur deposition in Northern China: insights into the potential acidification risks, Atmos. Chem. Phys., 13, 1675-1688, doi:10.5194/acp-13-16752013, 2013.

Pathak, R. K., Yao, X. H., and Chan, C. K.: Sampling artifacts of acidity and ionic species in $\mathrm{PM}_{2.5}$, Environ. Sci. Technol., 38, 254-259, doi:10.1021/Es0342244, 2004.

Pathak, R. K., Wu, W. S., and Wang, T.: Summertime $\mathrm{PM}_{2.5}$ ionic species in four major cities of China: nitrate formation in an ammonia-deficient atmosphere, Atmos. Chem. Phys., 9, 17111722, doi:10.5194/acp-9-1711-2009, 2009.

Pathak, R. K., Wang, T., Ho, K. F., and Lee, S. C.: Characteristics of summertime $\mathrm{PM}_{2.5}$ organic and elemental carbon in four major Chinese cities: Implications of high acidity for watersoluble organic carbon (WSOC), Atmos. Environ., 45, 318-325, doi:10.1016/j.atmosenv.2010.10.021, 2011.

Peltier, R. E., Sullivan, A. P., Weber, R. J., Wollny, A. G., Holloway, J. S., Brock, C. A., de Gouw, J. A., and Atlas, E. L.: No evidence for acid-catalyzed secondary organic aerosol formation in power plant plumes over metropolitan Atlanta, Georgia, Geophys. Res. Lett., 34, L06801, doi:10.1029/2006gl028780, 2007.

Pilinis, C. and Seinfeld, J. H.: Continued development of a general equilibrium model for inorganic multicomponent atmospheric aerosols, Atmos. Environ., 21, 2453-2466, doi:10.1016/00046981(87)90380-5, 1987.

Pszenny, A. A. P., Moldanová, J., Keene, W. C., Sander, R., Maben, J. R., Martinez, M., Crutzen, P. J., Perner, D., and Prinn, R. G.: Halogen cycling and aerosol $\mathrm{pH}$ in the Hawaiian marine boundary layer, Atmos. Chem. Phys., 4, 147-168, doi:10.5194/acp-4147-2004, 2004.

Reid, J. S., Hobbs, P. V., Ferek, R. J., Blake, D. R., Martins, J. V., Dunlap, M. R., and Liousse, C.: Physical, chemical, and optical properties of regional hazes dominated by smoke in Brazil, J. Geophys. Res.-Atmos., 103, 32059-32080, doi:10.1029/98jd00458, 1998.

Sander, R. and Crutzen, P. J.: Model study indicating halogen activation and ozone destruction in polluted air masses transported to the sea, J. Geophys. Res.-Atmos., 101, 9121-9138, doi:10.1029/95jd03793, 1996.

Schindler, D. W.: Effects of Acid-Rain on Fresh-Water Ecosystems, Science, 239, 149-157, doi:10.1126/science.239.4836.149, 1988.

Stoddard, J. L., Jeffries, D. S., Lukewille, A., Clair, T. A., Dillon, P. J., Driscoll, C. T., Forsius, M., Johannessen, M., Kahl, J. S., Kellogg, J. H., Kemp, A., Mannio, J., Monteith, D. T., Murdoch, P. S., Patrick, S., Rebsdorf, A., Skjelkvale, B. L., Stainton, M. P., Traaen, T., van Dam, H., Webster, K. E., Wieting, J., and Wilander, A.: Regional trends in aquatic recovery from acidification in North America and Europe, Nature, 401, 575-578, doi:10.1038/44114, 1999.

Stumm, W. and Morgan, J. J.: Aquatic chemistry : chemical equilibria and rates in natural waters, Wiley, New York, 1996.

Sun, Y.-L., Zhang, Q., Schwab, J. J., Demerjian, K. L., Chen, W.N., Bae, M.-S., Hung, H.-M., Hogrefe, O., Frank, B., Rattigan, O. V., and Lin, Y.-C.: Characterization of the sources and pro- cesses of organic and inorganic aerosols in New York city with a high-resolution time-of-flight aerosol mass apectrometer, Atmos. Chem. Phys., 11, 1581-1602, doi:10.5194/acp-11-15812011, 2011.

Surratt, J. D., Lewandowski, M., Offenberg, J. H., Jaoui, M., Kleindienst, T. E., Edney, E. O., and Seinfeld, J. H.: Effect of acidity on secondary organic aerosol formation from isoprene, Environ. Sci. Technol., 41, 5363-5369, doi:10.1021/Es0704176, 2007.

Takahama, S., Davidson, C. I., and Pandis, S. N.: Semicontinuous measurements of organic carbon and acidity during the Pittsburgh air quality study: Implications for acid-catalyzed organic aerosol formation, Environ. Sci. Technol., 40, 2191-2199, doi:10.1021/Es050856+, 2006.

Tanner, R. L., Olszyna, K. J., Edgerton, E. S., Knipping, E., and Shaw, S. L.: Searching for evidence of acid-catalyzed enhancement of secondary organic aerosol formation using ambient aerosol data, Atmos. Environ., 43, 3440-3444, doi:10.1016/j.atmosenv.2009.03.045, 2009.

Thornton, J. A., Kercher, J. P., Riedel, T. P., Wagner, N. L., Cozic, J., Holloway, J. S., Dube, W. P., Wolfe, G. M., Quinn, P. K., Middlebrook, A. M., Alexander, B., and Brown, S. S.: A large atomic chlorine source inferred from mid-continental reactive nitrogen chemistry, Nature, 464, 271-274, doi:10.1038/Nature08905, 2010 .

Trebs, I., Metzger, S., Meixner, F. X., Helas, G. N., Hoffer, A., Rudich, Y., Falkovich, A. H., Moura, M. A. L., da Silva, R. S., Artaxo, P., Slanina, J., and Andreae, M. O.: The $\mathrm{NH}_{4}^{+}-\mathrm{NO}_{3}^{-}-$ $\mathrm{Cl}^{-}-\mathrm{SO}_{4}^{2-}-\mathrm{H}_{2} \mathrm{O}$ aerosol system and its gas phase precursors at a pasture site in the Amazon Basin: How relevant are mineral cations and soluble organic acids?, J. Geophys. Res.-Atmos., 110, D07303, doi:10.1029/2004jd005478, 2005.

Wexler, A. S. and Clegg, S. L.: Atmospheric aerosol models for systems including the ions $\mathrm{H}^{+}, \mathrm{NH}_{4}^{+}, \mathrm{Na}^{+}, \mathrm{SO}_{4}^{2-}$, $\mathrm{NO}_{3}^{-}, \mathrm{Cl}^{-}, \mathrm{Br}^{-}$, and $\mathrm{H}_{2} \mathrm{O}$, J. Geophys. Res.-Atmos., 107, 4207, doi:10.1029/2001jd000451, 2002.

Winkler, P.: Relations Between Aerosol Acidity and Ion Balance, in: Chemistry of Multiphase Atmospheric Systems, edited by: Jaeschke, W., 6, Springer-Verlag, New York, 269-298, 1986.

Xu, L., Guo, H., Boyd, C. M., Klein, M., Bougiatioti, A., Cerully, K. M., Hite, J. R., Isaacman-VanWertz, G., Kreisberg, N. M., Knote, C., Olson, K., Koss, A., Goldstein, A. H., Hering, S. V., de Gouw, J., Baumann, K., Lee, S.-H., Nenes, A., Weber, R. J., and $\mathrm{Ng}, \mathrm{N}$. L.: Effects of anthropogenic emissions on aerosol formation from isoprene and monoterpenes in the southeastern United States, P. Natl. Acad. Sci. USA, 112, 37-42, doi:10.1073/pnas.1417609112, 2015.

Yao, X. H., Ling, T. Y., Fang, M., and Chan, C. K.: Comparison of thermodynamic predictions for in situ $\mathrm{pH}$ in $\mathrm{PM}_{2.5}$, Atmos. Environ., 40, 2835-2844, doi:10.1016/j.atmosenv.2006.01.006, 2006.

Young, A. H., Keene, W. C., Pszenny, A. A. P., Sander, R., Thornton, J. A., Riedel, T. P., and Maben, J. R.: Phase partitioning of soluble trace gases with size-resolved aerosols in near-surface continental air over northern Colorado, USA, during winter, J. Geophys. Res.-Atmos., 118, 9414-9427, doi:10.1002/Jgrd.50655, 2013.

Zaveri, R. A., Easter, R. C., Fast, J. D., and Peters, L. K.: Model for Simulating Aerosol Interactions and Chemistry (MOSAIC), J. Geophys. Res.-Atmos., 113, D13204, doi:10.1029/2007jd008782, 2008. 
Zhang, H. F., Worton, D. R., Lewandowski, M., Ortega, J., Rubitschun, C. L., Park, J. H., Kristensen, K., Campuzano-Jost, P., Day, D. A., Jimenez, J. L., Jaoui, M., Offenberg, J. H., Kleindienst, T. E., Gilman, J., Kuster, W. C., de Gouw, J., Park, C., Schade, G. W., Frossard, A. A., Russell, L., Kaser, L., Jud, W., Hansel, A., Cappellin, L., Karl, T., Glasius, M., Guenther, A., Goldstein, A. H., Seinfeld, J. H., Gold, A., Kamens, R. M., and Surratt, J. D.: Organosulfates as Tracers for Secondary Organic Aerosol (SOA) Formation from 2-Methyl-3-Buten-2-ol (MBO) in the Atmosphere, Environ. Sci. Technol., 46, 94379446, doi:10.1021/Es301648z, 2012a.

Zhang, Q., Jimenez, J. L., Worsnop, D. R., and Canagaratna, M.: A case study of urban particle acidity and its influence on secondary organic aerosol, Environ. Sci. Technol., 41, 3213-3219, doi:10.1021/Es061812j, 2007.
Zhang, X., Liu, Z., Hecobian, A., Zheng, M., Frank, N. H., Edgerton, E. S., and Weber, R. J.: Spatial and seasonal variations of fine particle water-soluble organic carbon (WSOC) over the southeastern United States: implications for secondary organic aerosol formation, Atmos. Chem. Phys., 12, 6593-6607, doi:10.5194/acp-12-6593-2012, 2012b.

Zhang, Y., Seigneur, C., Seinfeld, J. H., Jacobson, M., Clegg, S. L., and Binkowski, F. S.: A comparative review of inorganic aerosol thermodynamic equilibrium modules: similarities, differences, and their likely causes, Atmos. Environ., 34, 117-137, doi:10.1016/S1352-2310(99)00236-8, 2000.

Ziemba, L. D., Fischer, E., Griffin, R. J., and Talbot, R. W.: Aerosol acidity in rural New England: Temporal trends and source region analysis, J. Geophys. Res.-Atmos., 112, D10s22, doi:10.1029/2006jd007605, 2007. 